\title{
Structure, morphology, size and application of iron phosphate
}

https://doi.org/10.1515/rams-2020-0039

Received Apr 08, 2020; accepted Jul 17, 2020

\begin{abstract}
Iron phosphates have rich chemical structures with various morphologies and sizes. Since they are environment friendly with good biocompatibility, they have good performances in the fields of catalysis and battery electrode material rising in recent years, as well as in the traditional fields like agriculture and steel. They also have important applications in adsorption, separation and concentration due to their unique structural characteristics. In this paper, iron phosphates are classified based on their common characteristics such as structure, morphology and size, and their application in the past two decades is reviewed, with emphasis on their application in adsorption, separation and concentration of different species. Further, their application in adsorption, separation and concentration of heavy metals is prospected.
\end{abstract}

Keywords: iron phosphate, classification, application, adsorption

\section{Introduction}

Iron phosphates belong to a rather new group of materials whose interest is growing. They have rich chemical structures and their preparation methods are different with various characteristics. The synthesis methods of iron phosphates commonly used include hydrothermal method, solvothermal method, precipitation, coprecipitation, etc. Many structures of iron phosphates have been synthesized presently, including, $\alpha$-quartz, amorphous, monoclinic, orthorhombic, triclinic, and so on. The temperature and pressure have a great influence on the struc-

\footnotetext{
*Corresponding Author: Xiaoxing Zhang: College of Environmental Sciences and Engineering, Dalian Maritime University, Dalian 116026, China; Email: zhangxiaoxing@dlmu.edu.cn; Tel.: +86 411 84729205; Fax: +86 41184727670

Li Zhang, Hui Liu, Binxia Cao, Libo Liu, Weimin Gong: College of Environmental Sciences and Engineering, Dalian Maritime University, Dalian 116026, China
}

OO Open Access. (c) 2020 X. Zhang et al., published by De Gruyter. (Cc) BY License ture. At atmospheric pressure, it exists as an $\alpha$-quartz structure. And it becomes tetragonal under high pressure. The temperature change leads to an a- $\beta$ phase transition from a P622 to a P32 phase [1].

Early studies focused on microporous iron phosphate materials with open framework structure, and then mesoporous iron phosphate nanomaterials also attracted great attention of researchers due to their excellent performance in application. Now there have been reports on the synthesis of one-dimensional tube/rod/wire, two-dimensional disc/plate, three-dimensional nanoparticles, hollow spheres and other iron phosphate materials. This paper mainly introduces $\mathrm{FePO}_{4}$ with various crystal forms, sizes and morphologies. Since the iron phosphates are a wide group of compounds of different structural and chemical composition, some other compounds (e.g., $\mathrm{Fe}_{5}\left(\mathrm{PO}_{4}\right)_{4}(\mathrm{OH})_{2} \cdot 2 \mathrm{H}_{2} \mathrm{O}, \mathrm{Fe}_{4}\left(\mathrm{P}_{2} \mathrm{O}_{7}\right)_{3}$, $\left.\mathrm{Fe}_{3}\left(\mathrm{PO}_{4}\right)_{2} \cdot\left(\mathrm{H}_{2} \mathrm{O}\right)_{8}\right)$ and related composites (e.g., $\mathrm{FePO}_{4} / \mathrm{C}$, $\left.\mathrm{GO}-\mathrm{FePO}_{4}, \mathrm{Fe}_{3} \mathrm{O}_{4} @ \mathrm{FePO}_{4}\right)$ are also mentioned.

Iron phosphates were firstly applied in areas of agriculture, ceramic glass, steel, and surface passivation, etc. Later, especially in the past two decades, they have had good performances in the fields of catalytic and battery electrode materials since their unique catalytic and electric properties were found, which has greatly broadened the scope of their application. In addition, they have had important applications in fields of adsorption, separation and concentration due to their unique local structures, and have good application prospects.

In recent years, the author has paid great attention to the application of iron phosphates in the field of adsorption, separation and concentration of heavy metals, and has done some research work. In the process of consulting related literatures, it is found that the existing review articles generally focus on some aspects of work, and lack an overall introduction of this kind of material. In this paper, for the first time, iron phosphates are classified based on their common characteristics such as structure, morphology and size, and their application in various fields in the past two decades is reviewed, with emphasis on their application in adsorption, separation and concentration of different species. Further, their application in ad- 
sorption, separation and concentration of heavy metals is prospected. Such a review may be valuable for a broad scientific community, from scientists focusing on different synthesis methods, up to those targeting on applications. Thus, it should be interesting for chemists, materials scientists, physicist, etc.

\section{Classification of iron phosphate}

Iron phosphates, with various crystal forms, sizes and morphologies, can be synthesized using different synthesis methods. And their controllable preparation can be realized by adjusting the initial concentration of precursors or adding different reactants and templates. Separately, in terms of crystal form, there are amorphous, monoclinic, orthorhombic structures, etc.; in terms of morphology, there are solid spheres, hollow spheres, rods, tubes, flakes, flowers, branches, etc.; in terms of size, there are nanometer, micrometer, or larger scales; in terms of pore size, there are microporous, mesoporous, macroporous structures, etc. It is difficult to classify the synthesized products into a certain category accurately. Therefore, the products of iron phosphate are roughly classified according to their common and obvious characteristics in this section.

\subsection{Microporous iron phosphate}

Huang et al. [2] synthesized a microporous iron phosphate with an open framework structure by hydrothermal method, and its pore volume is $2957.5 \AA^{3}$. Hydrothermal organically templated magnetic iron phosphates with a three-dimensional open framework were synthesized by Riou-Cavellec et al. [3], the projection of which is shown in Figure 1 [3]. The hydrothermal method promoted the formation of open-framework iron phosphate. If fluoride ions were introduced into the hydrothermal process as a mineralizer, part of fluoride ions may participate in the composition of the framework structure, which is conductive to the synthesis of new phases and metal phosphates with supermicropores. The role of fluoride mineralizer is particularly obvious in the synthesis of open-framework iron phosphate [4]. A three-dimensional open framework iron phosphate which contains organic ethylenediammonium dication in the framework voids was synthesized under solvothermal conditions [5]. The most important feather of the compound is that it contains four coordinated iron atoms which is very rare in iron phosphates.

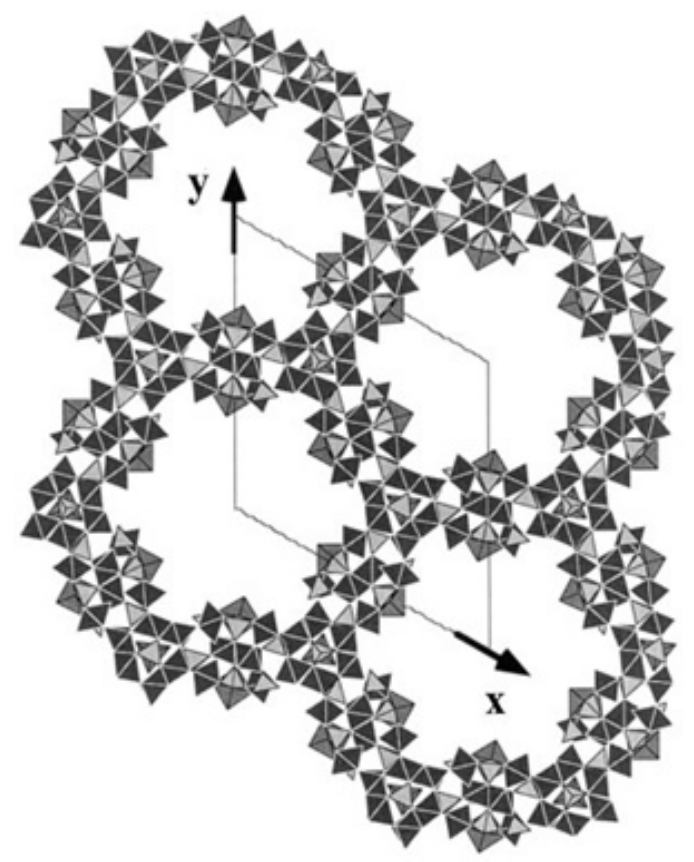

Figure 1: Projection of three-dimensional open structure of iron phosphate [3].

\subsection{Mesoporous iron phosphate}

It was reported for the first time by Guo et al. [6] of Nanjing University in 2000 that meso-structured lamellar iron phosphates with varied $d$-spacings were synthesized from ferric acetylacetonate and n-alkylammonium dihydrogenphosphates as both template and reactant. Then Guo [7] synthesized a novel mesoporous layered iron phosphate with a surface area of $254 \mathrm{~m}^{2} \mathrm{~g}^{-1}$ and average pore size of $2.6 \mathrm{~nm}$ by using hydrofluoric acid as mineralizer. The introduction of hydrofluoric acid can connect iron phosphate and anionic surfactant sodium dodecyl sulfate, and make iron phosphate aggregate on the surface of surfactant which is conducive to the synthesis of mesoporous structure. However, the mesoporous structure obtained by this method is disordered. Subsequently, Yu et al. [8] in Guo's research group synthesized well-ordered hexagonal mesoporous iron phosphate with a narrow pore diameter of $2.4 \mathrm{~nm}$ and the lattice period length of $4.5 \mathrm{~nm}$ and a surface area of $423 \mathrm{~m}^{2} \mathrm{~g}^{-1}$ by using the similar method as above [7]. Santos-Pena et al. [9] also synthesized amorphous $\mathrm{FePO}_{4} \cdot 2 \mathrm{H}_{2} \mathrm{O}$ composed of nanoparticles with size of 40-80 $\mathrm{nm}$ by using a similar method [7]. The mesophase obtained by using CTAB as a template, is more ordered compared with the literature [7]. Using cationic surfactant CTMACl as the template, Zhu et al. [10] synthesized a highly-ordered hexagonally mesostructured iron phos- 
phate with a d spacing of $4.18 \mathrm{~nm}$ and a lattice constant of $4.82 \mathrm{~nm}$.

Bastakoti et al. [11] synthesized large-sized mesoporous iron phosphate with $30 \mathrm{~nm}$ pore diameter and 15 $\mathrm{nm}$ wall thickness by a soft-template method based on polymeric micelles assembly. Pramanik et al. [12] reported the shape controlled synthesis of crystalline mesoporous iron phosphate with 2D-plates and 1D-rods, the dimensionality of which can be switched by changing the polarity of the synthetic medium. Shi et al. [13] prepared mesoporous $\mathrm{FePO}_{4}$ by a modified template method using P123 surfactant as a template with further calcination below $500^{\circ} \mathrm{C}$. El Haskouri et al. [14] synthesized relatively high surface area mesoporous iron phosphate through a generalized one-pot procedure by using a cationic surfactant as co-assembling template. A soft chemical extraction procedure allows opening the pore system of the parent as-prepared materials by exchanging the surfactant without mesostructure collapse. The final solids pose a wellestablished oxo-phosphate-based mesostructure, without segregation of metal oxide domains.

\subsection{Microspheres}

$\mathrm{Fe}_{5}\left(\mathrm{PO}_{4}\right)_{4}(\mathrm{OH})_{2} \cdot 2 \mathrm{H}_{2} \mathrm{O}$ spheres with a diameter of ca. 5 $\mu \mathrm{m}$ were formed through hydrothermal reaction. After carbonization at $500^{\circ} \mathrm{C}, \mathrm{Fe}_{3}\left(\mathrm{PO}_{4}\right)_{2}(\mathrm{OH})_{2}$ spheres coated with carbon were obtained [15]. Iron hydroxyl phosphate $\mathrm{Fe}_{3}\left(\mathrm{PO}_{4}\right)_{2}(\mathrm{OH})_{2}$ microspheres with diameters of several micrometers were prepared by a facile one-step glycerinassisted solvothermal method. The microspheres have good biocompatibility and can transform into $\mathrm{FePO}_{4}$ through thermal treatment at $800^{\circ} \mathrm{C}$ in the air [16]. Monodispersed $\mathrm{Fe}_{5}\left(\mathrm{PO}_{4}\right)_{4}(\mathrm{OH})_{3} \cdot 2 \mathrm{H}_{2} \mathrm{O}$ microspheres were prepared by a one-step hydrothermal method without templates [17]. The microspheres, with diameters of 1.0$3.0 \mu \mathrm{m}$, are constructed by the polyhedral nanoparticles with an average diameter of $100 \mathrm{~nm}$. The corresponding $\mathrm{FePO}_{4}$ microspheres assembled by mesoporous polyhedral nanocrystals can be obtained after calcination. Sphere $\mathrm{FePO}_{4}$ with a diameter of $15 \mu \mathrm{m}$, controllably synthesized by a hydrothermal route with the molar ratio $\mathrm{FeCl}_{3} / \mathrm{KH}_{2} \mathrm{PO}_{4}$ of 3:3, was consisted of small nanoparticles $(<50 \mathrm{~nm})$ [18].

\subsection{Hollow spheres}

Li's team obtained hollow colloidal spheres of iron phosphate by low-temperature solution-phase reactions [19]. The size of the colloidal spheres can be easily controlled by adjusting the concentration of the precursor. No visible change in particle size and morphology after annealing at $500^{\circ} \mathrm{C}$. The colloidal spheres are stable, negatively charged, and well-dispersed in solution. Cao et al. [20]
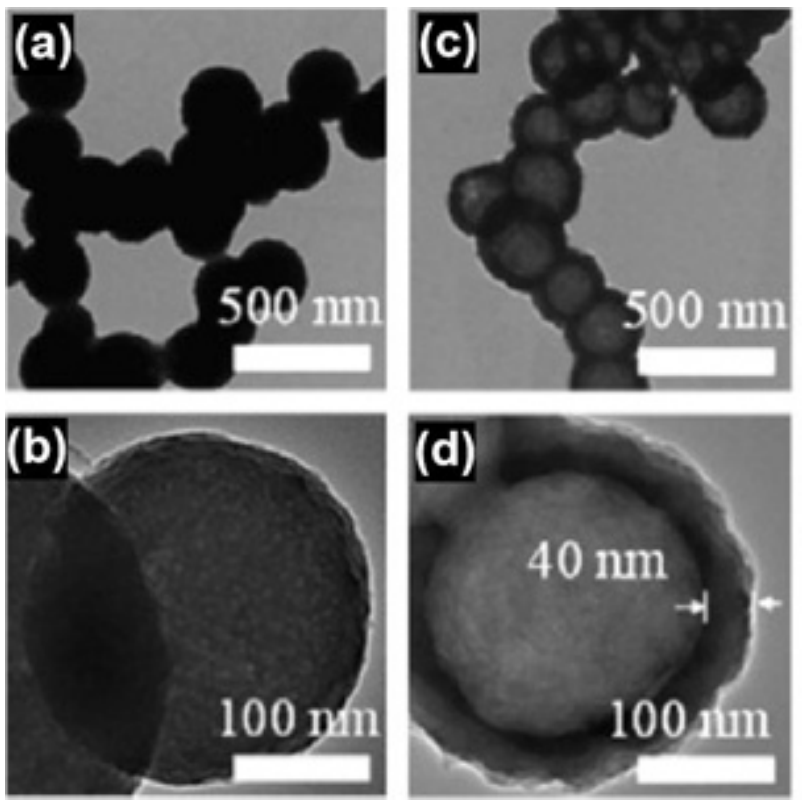
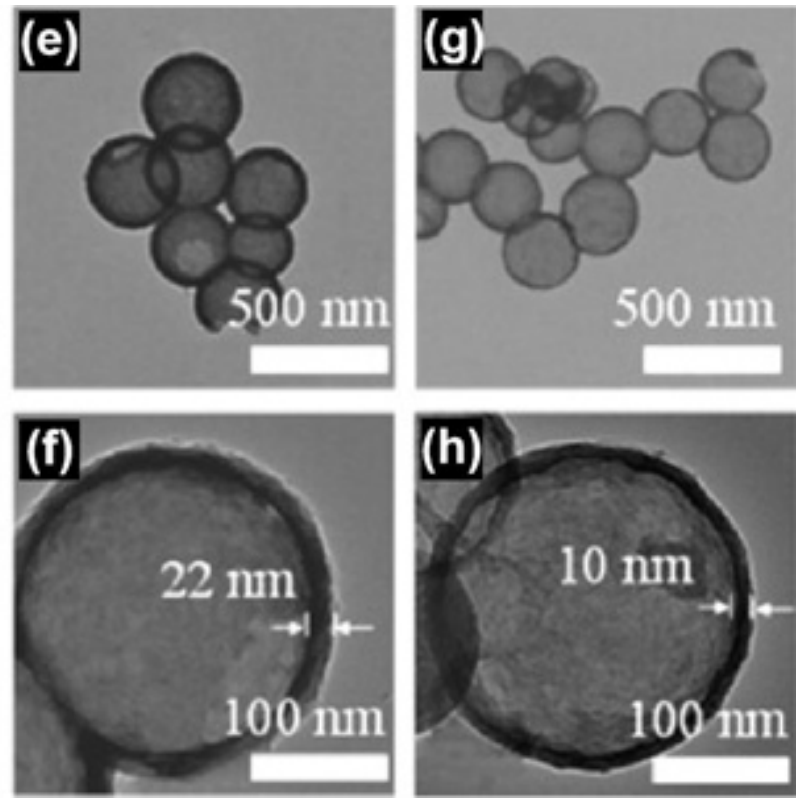

Figure 2: TEM images of $\mathrm{FePO}_{4}$ nanospheres synthesized at the molar ratio of $\mathrm{Fe}^{2+} / \mathrm{PO}_{4}^{3-}$ of 1:1 (a, b), 1:2 (c, d), 1:3 (e, f), and 1:4 (g, h), respectively. (a) and (b) are solid nanospheres, (c)-(h) are hollow nanospheres with the shell thickness of approximately 40 (c, d), 22 (e, f), and $10 \mathrm{~nm}(\mathrm{~g}, \mathrm{~h})$, respectively [22]. 
prepared monodispersed iron phosphate hollow microspheres with a high degree of crystallization through a facile in-situ deposition method using rape pollen grains as a biotemplate. Cao et al. [21] synthesized iron hydroxyl phosphate microspheres with the core in the hollow shell, and double-shelled hollow microspheres by a simple one-step microwave-solvothermal ionic liquid method. Yin et al. [22] synthesized amorphous $\mathrm{FePO}_{4}$ hollow nanospheres with tunable shell thickness by a one-step hydrothermal approach, as shown in Figure 2 [22]. A similar method [22] was used to grow amorphous $\mathrm{FePO}_{4}$ hollow nanospheres directly on the surface of graphene [23]. The outer diameter of the nanospheres is ca. $30-60 \mathrm{~nm}$, hollowstructured with a wall thickness of 4-6 $\mathrm{nm}$.

\subsection{Nanometer iron phosphate}

\section{Nanoparticle}

The precipitation method is commonly used in preparing iron phosphate nanoparticles. Guo et al. [24] prepared iron phosphate nanoparticles by quick homogeneous precipitation with an amorphous structure. Compared with that obtained by the general precipitation method, the size and morphology of the particles have a better dispersion, and the particle size uniformity $(15-25 \mathrm{~nm})$ is significantly better than the latter $(5-80 \mathrm{~nm})$. Wang et al. [25] synthesized amorphous $\mathrm{FePO}_{4} \cdot 2 \mathrm{H}_{2} \mathrm{O}$ nanoparticles with average particle size of $80 \mathrm{~nm}$ by a facile coprecipitation method at ambient temperature. Lu et al. [26] prepared nanosized iron phosphate, with high purity, well dispersion and narrow size distribution around $59 \mathrm{~nm}$, by coupling fast precipitation in membrane dispersion microcontactor and hydrothermal treatment. Zhang et al. [27] conducted the size adjustment of $\mathrm{FePO}_{4}$ nanoparticles in the range of 9-50 $\mathrm{nm}$ by using mixed acids on a general platform of coupling fast precipitation and thermal treatment process. The as-prepared nanoparticles were highpurity amorphous $\mathrm{FePO}_{4} \cdot 2 \mathrm{H}_{2} \mathrm{O}$ with good dispersity and narrow size distribution. Fang et al. [28] synthesized $\mathrm{FePO}_{4}$ nanospheres successfully through a simple chemically induced precipitation method with a diameter of ca. $100 \mathrm{~nm}$. The nanospheres present a mesoporous amorphous structure with pore size of ca. $10 \mathrm{~nm}$ and surface area of 19.33 $\mathrm{m}^{2} \mathrm{~g}^{-1}$.

Compared with conventional precipitation method, $\mathrm{FePO}_{4} \cdot 2 \mathrm{H}_{2} \mathrm{O}$ prepared by microreaction technology shows a uniformly distributed granular morphology with a smaller mean size of ca. $200 \mathrm{~nm}$ [29]. Additionally, Yang et al. [30] achieved the direct formation of iron phosphate nanoparticles on hydroxyl-terminated $\mathrm{SiO}_{2} / \mathrm{Si}$ substrates with a narrow size distribution (average diameter $=2.2$ $\mathrm{nm}$ ) by a simple room temperature spontaneous reaction of ferric chloride and phosphoric acid. Yin et al. [31] synthesized amorphous iron(III) phosphate by solid-state reaction at room temperature. The particle size is in the range of 100-200 $\mathrm{nm}$. Yin et al. [32] synthesized iron phosphate nanostructures by a fast, simple microwave heating method. The morphology and size of the nanomaterials are significantly influenced by the concentration of the precursors and the kinds of surfactants. Qian et al. [33] synthesized unique amorphous $\mathrm{FePO}_{4}$ with particle size of 20-80 $\mathrm{nm}$ by a new cost-effective electrochemical method. This $\mathrm{FePO}_{4}$ possesses a mesoporous structure with specific surface area of $65.2 \mathrm{~m}^{2} \mathrm{~g}^{-1}$ and dominant pore diameter of $23.6 \mathrm{~nm}$. Liu et al. [34] reported a novel strategy using a confined area impinging jet reactor to continuously produce amorphous $\mathrm{FePO}_{4}$ nanoparticles within 10-30 nm. The particles transform into trigonal iron phosphate and the size turns to $40-60 \mathrm{~nm}$ after calcination at $600^{\circ} \mathrm{C}$. Yang et al. [35] synthesized $\mathrm{FePO}_{4}$ with well-defined ellipsoid morphology and uniform particle size distribution via a green spray drying method with formic acid as additive. The material consisting of ellipsoid particles (ca. $100 \mathrm{~nm}$ ) has a higher specific surface $\left(13.45 \mathrm{~m}^{2} \mathrm{~g}^{-1}\right)$. The added formic acid plays a crucial role in the formation of the welldistributed $\mathrm{FePO}_{4}$ particles.

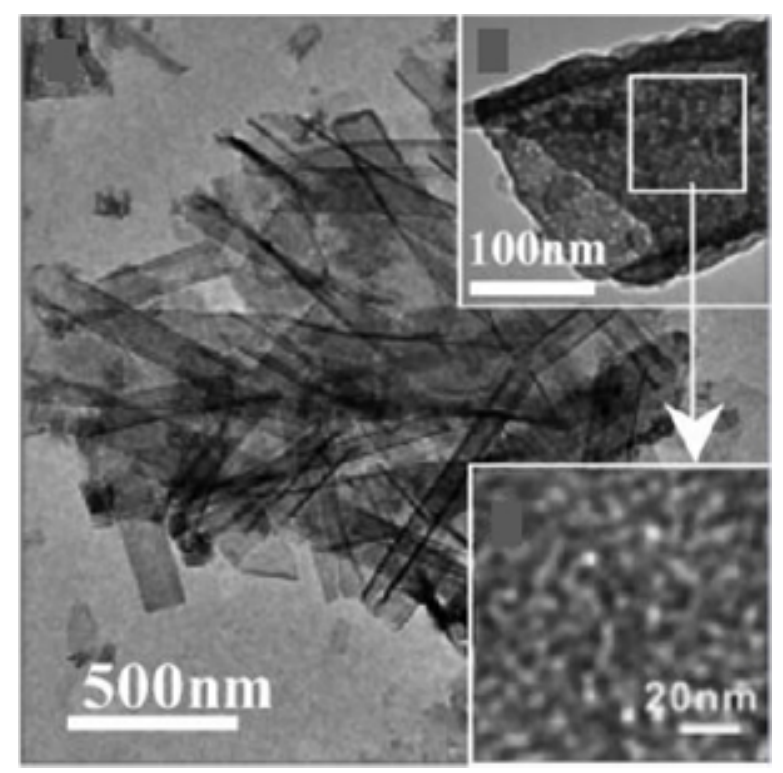

Figure 3: TEM images of nanotubular iron phosphate with mesoporous structure [36]. 


\section{Nanotube}

On the basis of the concepts developed in the previous synthesis of mesoporous iron phosphate [7], iron phosphate nanotubes with mesoporous walls are solvothermally synthesized, with diameters of 50-400 nm, lengths of several microns, and wall thickness of $20-40 \mathrm{~nm}$ [36]. The novel nanotubular iron phosphate with composite mesomacroporous structure possesses a specific surface area of $232 \mathrm{~m}^{2} \mathrm{~g}^{-1}$ and bimodal distribution of pore sizes with two maxima at $\sim 3 \mathrm{~nm}$ and $\sim 50 \mathrm{~nm}$, respectively, as shown in Figure 3 [36]. Cai et al. [37] reported an oil-phase synthesis of uniform double-wall amorphous $\mathrm{FePO}_{4}\left(\alpha-\mathrm{FePO}_{4}\right)$ nanotubes with each wall thickness of only $\sim 20 \mathrm{~nm}$.

\section{Nanorod/nanowire}

Iron phosphate nanorods $\left(\mathrm{FePO}_{4}\right.$ particles with the nanorod shape) were synthesized via a novel facile route.
The diffraction lines were indexed to the hexagonal structure $[38,39]$. The diameter of these nanorods is about in the range of 20-30 nm and the length 50-100 nm.

Amorphous $\alpha$ - $\mathrm{FePO}_{4} \cdot \mathrm{H}_{2} \mathrm{O}$ nanowires with diameters of $10-20 \mathrm{~nm}$ were synthesized using genetically engineered M13 virus [40], as shown in Figure 4 [40].

\section{Nanosheet/nanoplate/nanoflake}

Ultra-thin iron phosphate nanosheets, with some mesoporous morphologies, were designed as a new 2D material with high surface area of $27.77 \mathrm{~m}^{2} \mathrm{~g}^{-1}$ [41].

Amorphous $\mathrm{FePO}_{4} \cdot 2 \mathrm{H}_{2} \mathrm{O}$ nanoplates were prepared via liquid exfoliation method [42]. The nanoplates were exfoliated from the diethylamine-modified $\mathrm{FePO}_{4} \cdot 2 \mathrm{H}_{2} \mathrm{O}$ that were sourced from recycled steelmaking slag. The obtained nanoplates feature in an average lateral size of 46.76 $\mathrm{nm}$ and transversal size of $31.62 \mathrm{~nm}$ with an average thickness of $30.4 \mathrm{~nm}$.

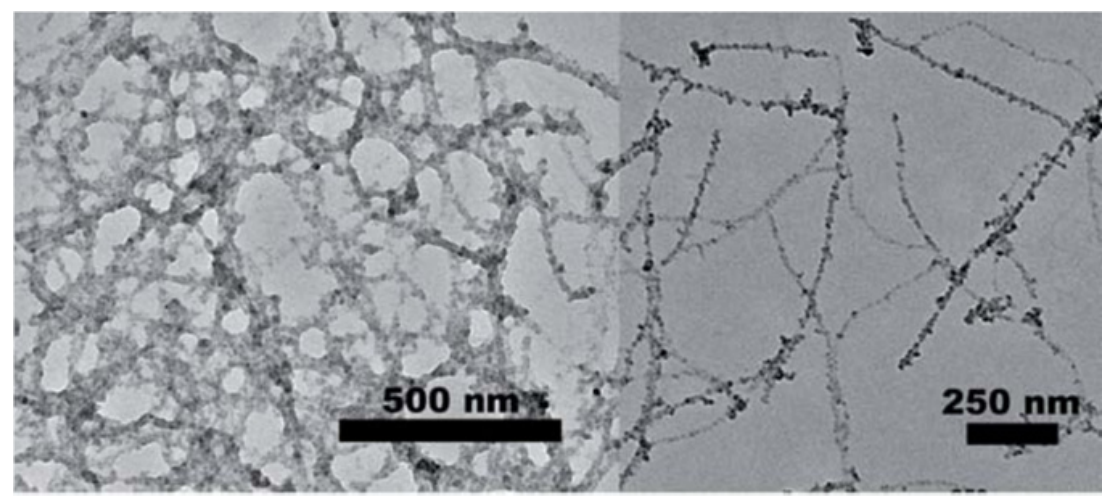

Figure 4: TEM images of $\alpha$ - $\mathrm{FePO}_{4} \cdot \mathrm{H}_{2} \mathrm{O}$ nanowires [40].
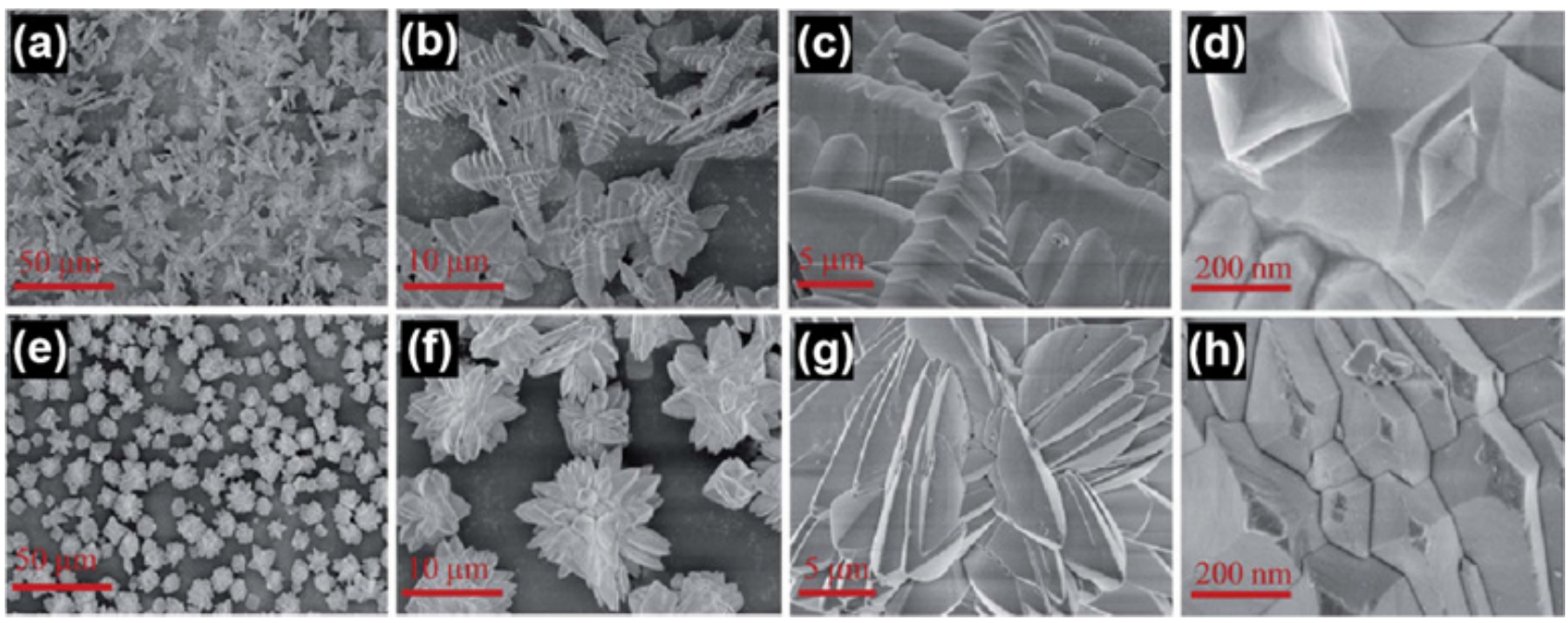

Figure 5: SEM images of branch-like (A-D), flower-like (E-H) $\mathrm{FePO}_{4}[18]$. 
Iron phosphate nanopowders were synthesized by precipitation method with yeast cells as a biologic template [43]. The product calcined shows flake shapes with length of 500-600 $\mathrm{nm}$ and width of 200-300 $\mathrm{nm}$. Ultrathin 2D nanoflakes of $\mathrm{FePO}_{4}$ were synthesized with highly ordered mesoporous structures [44]. The thicknesses of the as-obtained nanoflakes are about $3.7 \mathrm{~nm}$.

\subsection{Others}

The $\mathrm{FePO}_{4} \cdot 2 \mathrm{H}_{2} \mathrm{O}$ submicrometer-discs with a diameter of 1-1.5 $\mu \mathrm{m}$ and thickness of 300-500 $\mathrm{nm}$ were prepared by a facile heat reflux method [45]. Without using any templates and additive, the prepared material is single-phase monoclinic $\mathrm{FePO}_{4} \cdot 2 \mathrm{H}_{2} \mathrm{O}$ without any impurities phase. Ultrafine disc-shaped $\mathrm{FePO}_{4} \cdot 2 \mathrm{H}_{2} \mathrm{O}$ with a diameter of 1-5 $\mu \mathrm{m}$ and thickness of $0.5-1 \mu \mathrm{m}$ was prepared by the hydrogen peroxide-assisted oxidation with reduced iron powder and phosphoric acid as precursors [46]. No obvious agglomeration was observed.

Two new iron(III) phosphates were synthesized from the dehydration of hydrothermally prepared monoclinic and orthorhombic hydrated phosphates [47]. Both of the phases are thermally unstable relative to the trigonal quartz-like $\mathrm{FePO}_{4}$. Lin et al. [48] designed novel routes via phosphation of beta-FeOOH nanorods for the controlled synthesis of iron phosphate dihydrates of varying crystallographic phases (monoclinic and orthorhombic) and morphologies.

$\mathrm{FePO}_{4}$ with branch-like and flower-like morphologies (Figure 5 [18]) were achieved with the molar ratio $\mathrm{FeCl}_{3} / \mathrm{KH}_{2} \mathrm{PO}_{4}$ of 1:3 and 2:3, respectively [18]. The branchlike $\mathrm{FePO}_{4}$ consisted of four main branches, of which the length and the width were $10 \mu \mathrm{m}$ and $2 \mu \mathrm{m}$, respectively. The flower-like $\mathrm{FePO}_{4}$ with the particle diameter of around $10 \mu \mathrm{m}$ was regularly formed from a small branch structure of $200 \mathrm{~nm}$. Iron hydroxyl phosphate with various morphologies such as star-like and flower-like structures were also obtained by controlling the experimental parameters [21].

The investigation on the crystallization of iron phosphate glasses shows that the structure of phosphate glass changes from metaphosphate chain structures to the pyrophosphate and eventually, to orthophosphate structures with increasing $\mathrm{Fe}_{2} \mathrm{O}_{3}$ content [49]. The doping of $\mathrm{Al}_{2} \mathrm{O}_{3}$, $\mathrm{SiO}_{2}$ or $\mathrm{B}_{2} \mathrm{O}_{3}$ might improve the thermal stability of iron phosphate glasses [50].

\section{Application of iron phosphate}

This section introduces the application of iron phosphates in other fields except that in adsorption, separation and concentration, which will be focused on in the next section.

\subsection{Immobilization of chemical wastes}

Vitrification is the most effective method for the immobilization of hazardous waste by incorporating toxic elements into a glass structure for safe storage and burying. Iron phosphate glasses have been studied for their potential waste immobilization applications since the mid-1990s [51]. They have been proposed as matrices for the storage of radioactive waste, even those that cannot be vitrified using conventional borosilicate waste glass. The effect of different proportions of additives on their performance was studied in literatures [52, 53]. A model based on the crystal structure of $\mathrm{FePO}_{4}$ was optimized using the DFT method and corresponding theoretical spectroscopic studies [54]. The maximal predicted load of waste constituents into the glass without rebuilding of the structure is $30 \mathrm{~mol} \%$. The amorphous and crystalline structures of iron phosphate were investigated as candidate materials for encapsulation of nuclear waste [55]. An iron phosphate ceramic waste form was developed to immobilize radioactive waste solution using converter slag which is a by-product of the steel industry [56].

\subsection{Anti-corrosion}

As a pollution-free auxiliary agent in the anticorrosive paint, $\mathrm{FePO}_{4} \cdot 2 \mathrm{H}_{2} \mathrm{O}$ can replace the toxic agents such as red lead, lead chrome yellow and zinc chrome yellow etc. It can form a passivation film on the surface of steel to prevent air and water erosion [57, 58]. Electrocrystallization mechanism of iron phosphate coatings onto mild steel electrode surfaces was studied [59]. The formation of a thin and continuous iron phosphate layer showed an improvement in anti-corrosion behavior in the research of electrochemical corrosion behaviour of sintered composites [60].

\subsection{Plant nutrition and fertilization}

$\mathrm{FePO}_{4}$ can be applied in the field of plant nutrition and fertilization. The research indicates that $\mathrm{FePO}_{4} \mathrm{NPs}$ prepared by continuous industrially scalable method improved the 
availability of $\mathrm{P}$ and Fe for two hydroponically grown crop species compared with bulk $\mathrm{FePO}_{4}$ [61]. Modified iron phosphate/polyvinyl alcohol composite film was designed as a new concept of controlled-release $P$ fertilizer via incorporation of $\mathrm{FePO}_{4}$ as a $\mathrm{P}$ source in polyvinyl alcohol films, which offers a new opportunity for the application of insoluble phosphate as a phosphorous fertilizer [62].

\subsection{Food additive}

Iron phosphate can be used as an additive for food and feed, as a quality improver and iron fortifier. Food fortification with iron phosphate is a promising new approach to reducing iron deficiency and $\mathrm{FePO}_{4}$ nanoparticles combine high bioavailability with superior sensory performance in difficult-to-fortify foods. It can be as safe for ingestion as $\mathrm{FeSO}_{4}$, a commonly used food fortification $[63,64]$.

\subsection{Sensing}

Iron phosphate nanoparticles can be used as materials for thin film optical waveguide due to its high transparency, high refractive index and good film-forming property. The bromothymol blue film-iron phosphate nano film $/ \mathrm{K}^{+} \mathrm{ex}-$ changed glass composite optical waveguide sensing unit was developed to detect ammonia vapor with a detection limit of $0.35 \mathrm{mg} \mathrm{m}^{-3}$. It has features of fast response (10 s), short recovery time (90 s), good reversibility and reusability [65]. Iron phosphate nanoparticles were also employed as an electrode substrate to immobilize myoglobin $(\mathrm{Mb})$ [32]. The $\mathrm{Mb}-\mathrm{FePO}_{4} / \mathrm{GC}$ electrode displays good features in the electrocatalytic reduction of $\mathrm{H}_{2} \mathrm{O}_{2}$ and can be used as a biosensor for detecting substrates with a low detection limit of $5 \pm 1 \mu \mathrm{M}$. This study provides a simple and effective biosensing platform for the integration of proteins/enzymes and electrodes.

\subsection{Catalyst}

Iron phosphate can be used as a catalyst for selective oxidation. The selective oxidation of methane was catalyzed by iron phosphate with $\mathrm{O}_{2}, \mathrm{H}_{2} \mathrm{O}_{2}$ or $\mathrm{N}_{2} \mathrm{O}$ as oxidant [66]. Fe-P-O based catalysts in the gas-phase direct oxidation of benzene to phenol with $\mathrm{N}_{2} \mathrm{O}$ as an oxidant are similar to the non-zeolite iron containing catalysts with high selectivity like FeZSM-5 [67]. The tetrahedral coordinated $\mathrm{FeO}_{4}$ would play an important role during the reaction.
Compared with the crystalline sample, the mesoporous iron phosphate revealed better catalytic performance in the hydroxylation reaction of phenol in glacial acetic acid by hydrogen peroxide [8]. Catalytic behaviour of mesoporous iron phosphate in the gas-phase glycerol transformation exhibited a higher yield to acrolein than the other simple phosphates, which possess a high crystalline character [68]. Nanotubular iron phosphate with composite meso-macroporous structure, in favor of the diffusion of reactive molecules, showed better catalytic performance compared with the conventional particulate mesoporous iron phosphate in the direct hydroxylation of benzene with hydrogen peroxide [36]. Compared with flower-like, spherical and amorphous $\mathrm{FePO}_{4}$, branch-like $\mathrm{FePO}_{4}$ presented a better catalytic performance in the cellulose conversion into 5-HMF [18]. In addition, novel 1,4-DHPs are prepared efficiently using aldehydes, benzylacetoacetate and catalytic amount of iron(III) phosphate under solvent-free conditions in good yields [69].

SILAR deposited iron phosphate as a bifunctional electrocatalyst for efficient water splitting was studied, which may provide a facile and scalable approach to design a high-efficiency, earth abundant electrocatalyst for water splitting [70]. With the introduction of graphene oxide, enhanced photo-Fenton degradation of rhodamine $B$ was observed using $\mathrm{GO}-\mathrm{FePO}_{4}$ composites as effective and stable heterogeneous catalyst [71]. $\mathrm{GO}-\mathrm{FePO}_{4}$ also displayed improved photocatalytic activities compared to pure $\mathrm{FePO}_{4}$ in the degradation of methylene blue under simulated sunlight irradiation [72].

\subsection{Battery electrode material}

Iron phosphate has attracted extensive interest as a potential cathode material for Li-ion batteries. As a precursor, the synthesis methods, morphology, size, doping of $\mathrm{FePO}_{4}$ may affect the performance of batteries [73]. Goodenough et al. [74] firstly reported in 1997 that the olivine $\mathrm{LiFePO}_{4}$ could realize reversible extraction and insertion of lithium with a theoretical specific capacity of $170 \mathrm{~mA} \mathrm{~h} \mathrm{~g}^{-1}$. It is considered to be an ideal candidate for the cathode of a low-power, rechargeable lithium battery that is inexpensive, nontoxic, and environmentally benign. $\mathrm{LiFePO}_{4}$ was synthesized in the presence of high-surface area carbonblack as the cathode material of lithium battery [75]. Its discharge capacity can reach $170 \mathrm{~mA} \mathrm{~h} \mathrm{~g}^{-1}$ with good cycle stability. The cell was cycled for over 230 cycles with an average specific capacity of about $95 \mathrm{~mA} \mathrm{~h} \mathrm{~g}^{-1}$. The discharge capacity of amorphous nanoparticles $\mathrm{FePO}_{4} \cdot 2 \mathrm{H}_{2} \mathrm{O}$ as cathode materials is about twice that of crystalline iron phos- 
phate [25]. A mesoporous structure imported into $\mathrm{FePO}_{4}$ could improve lithium intercalation/deintercalation kinetics of electrode materials for rechargeable lithium batteries. Mesoporous $\mathrm{FePO}_{4}$ could deliver $120 \mathrm{mAh} \mathrm{g}^{-1}$, which was higher than that of reported amorphous and crystalline $\mathrm{FePO}_{4}$ [13]. With the preparation of mesoporous iron phosphate, one promising lithium ion electrode was obtained providing a stable capacity close to $100 \mathrm{~mA} \mathrm{~h} \mathrm{~g}^{-1}$ [9]. Amorphous iron phosphate nanowires were used for lithium ion battery cathodes. The first discharge capacity at a discharge rate of $\mathrm{C} / 10$ and $1 \mathrm{C}$ was $165 \mathrm{mAh} \mathrm{g}^{-1}$ (93\% of the theoretical value) and $110 \mathrm{mAh} \mathrm{g}^{-1}$, respectively [40]. The double-wall $\alpha$-FePO 4 nanotubes show interesting properties as a cathode material for $\mathrm{Li}$ ion battery, delivering a specific capacity of $125 \mathrm{mAh} \mathrm{g}^{-1}$ at a current density of $35.6 \mathrm{~mA} \mathrm{~g}^{-1}$ [37]. Amorphous $\mathrm{FePO}_{4}$ hollow nanospheres directly grown on graphene were used as a cathode material in lithium ion batteries [23]. This hybrid exhibits high rate capability and good cycle stability because of efficient $\mathrm{Li}^{+}$ion diffusion through the thin wall of the hollow nanospheres and fast electron transport through the graphene. The discharge capacity saturates to $174 \mathrm{mAh} \mathrm{g}^{-1}$ after 5 cycles, with high reversibility, and maintains a reversible capacity after 50 cycles of approximately $173 \mathrm{mAh} \mathrm{g}^{-1}$. Compared with the traditional precipitation method, the cycling stability and rate performance of the $\mathrm{LiFePO}_{4} / \mathrm{C}$ material synthesized by micro reaction technology significantly improved [29]. The discharge capacity reaches $162.7,153.6,142.7,130.6$ and $117.6 \mathrm{mAh} \mathrm{g}^{-1}$ at the rate of $0.1,1,2,3$ and $5 \mathrm{C}$, respectively. A facile strategy to construct composites of amorphous $\mathrm{FePO}_{4}$ nanoparticles and carbon additives with high dispersion and tap density was developed as cathodes of lithium-ion batteries [76]. Hybrid carbon additives were uniformly introduced into the $\alpha$-FePO4 cathode to form a hierarchical 3D conductive network. the reversible discharge capacity could reach $175.6 \mathrm{mAh} \mathrm{g}^{-1}$ at $0.1 \mathrm{C}$ and $139.1 \mathrm{mAh} \mathrm{g}^{-1}$ at $5 \mathrm{C}$.

Recently, there have also been some reports about its application as electrode materials for other batteries such as Na-ion battery, Mg-ion battery, Li-S battery, etc. The findings indicated that amorphous $\mathrm{FePO}_{4}$ could be transformed into active $\mathrm{NaFePO}_{4}$, which may have great potential as an electrode material for Na-ion batteries. The amorphous $\mathrm{FePO}_{4}$ shows better electrochemical performance in terms of cyclic stability and discharge capacity, compared with trigonal $\mathrm{FePO}_{4}$ [77]. $\mathrm{FePO}_{4} / \mathrm{C}$ nanospheres demonstrate a high initial discharging capacity of $151 \mathrm{mAh} \mathrm{g}^{-1}$ at $20 \mathrm{~mA} \mathrm{~g}^{-1}$, stable cyclability ( $94 \%$ capacity retention ratio over 160 cycles), as well as high rate capability (44 $\mathrm{mAh} \mathrm{g}^{-1}$ at $1000 \mathrm{~mA} \mathrm{~g}^{-1}$ ) for Na-ion storage [28]. $\mathrm{FePO}_{4} / \mathrm{C}$ prepared via electrochemical delithiation of $\mathrm{LiFePO}_{4} / \mathrm{C}$ is directly used as the cathode material for rechargeable $\mathrm{Mg}$ ion batteries, and reversible capacity is achieved for the first time [78]. Huang et al. [79] synthesized hollow $\mathrm{FePO}_{4}$ spheres wrapped by reduced graphene oxide as an efficient sulfur host material. The material showed impressive cycle stability with a low capacity decay rate of $0.037 \%$ per cycle at $0.5 \mathrm{C}$ upon 1000 cycles, suggesting its enormous potential for high-performance of Li-S battery.

\section{Application of iron phosphate in adsorp- tion/separation/concentration}

Iron phosphates have good biocompatibility and important applications in biology. And, the unique local structures of iron phosphates have the potential for the adsorption of various species of environmental significance, especially metal ions. Some of their important applications in adsorption, separation and concentration in recent years are as follows. Table 1 summarizes some typical applications on metals.

\section{$4.1 \mathrm{H}_{2} \mathrm{O}$}

The study investigated the controlling on size and adsorptive properties of spherical ferric phosphate particles [80]. The amorphous spherical ferric phosphate particles showed high selective adsorption of $\mathrm{H}_{2} \mathrm{O}$ by penetration of $\mathrm{H}_{2} \mathrm{O}$ molecules into ultramicropores. The more particles grew, the more adsorption selectivity of $\mathrm{H}_{2} \mathrm{O}$ became remarkable.

\subsection{Biomolecules}

Iron phosphate was reported for the selective adsorption of specific protein species from human whole blood by Wang's team in 2011 [81]. The favorable selectivity toward cytochrome $\mathrm{c}$ in the presence of acidic and neutral proteins could be obtained under controlled experimental conditions, with a theoretical adsorption capacity of $37.59 \mu \mathrm{g} \mathrm{mg}^{-1}$. No conformational change for cytochrome c after the adsorption and desorption processes, demonstrating the favorable biocompatibility of the as-prepared iron phosphate. In 2015, the team found a spherical polyethyleneimine-iron phosphate nanocomposite with a size of ca. $100 \mathrm{~nm}$ showing favorable selective adsorption to DNA against proteins [82]. The adsorption behavior fits 
Table 1: Applications of iron phosphate in adsorption, separation and concentration of metals in recent years.

\begin{tabular}{|c|c|c|c|c|}
\hline Adsorbent & Metals & $\begin{array}{l}\mathrm{AC}^{a} \\
\left(\mathrm{mg} \mathrm{g}^{-1}\right)\end{array}$ & Mechanism & Ref. \\
\hline $\mathrm{Fe}_{7}\left(\mathrm{PO}_{4}\right)_{6}$ nanosheets & $\mathrm{U}(\mathrm{VI})$ & 704.23 & Monolayer Surface Complexation and Stacking mode & [41] \\
\hline Nano hierarchical Fe ${ }_{4}\left(\mathrm{P}_{2} \mathrm{O}_{7}\right)_{3}$ & $\mathrm{U}(\mathrm{VI})$ & 14 & Inner-sphere surface complexation & [83] \\
\hline $\mathrm{FePO}_{4}$ & $\begin{array}{l}\mathrm{Li}^{+}, \mathrm{Na}^{+}, \mathrm{K}^{+}, \\
\mathrm{Ca}^{2+}, \mathrm{Mg}^{2+}, \\
\mathrm{Zn}^{2+}, \mathrm{Cu}^{2+}, \\
\mathrm{Ni}^{2+}, \mathrm{Co}^{2+}\end{array}$ & & Ion exchange & [84-88] \\
\hline PFP & $\mathrm{Cd}^{2+}$ & & Co-precipitation & {$[90]$} \\
\hline Amorphous $\mathrm{FePO}_{4}$ & $\begin{array}{l}\mathrm{Hg}(\mathrm{II}) \\
\mathrm{Ag}(\mathrm{I})\end{array}$ & $\begin{array}{l}1.831^{b} \\
1.354^{b}\end{array}$ & & [31] \\
\hline $\begin{array}{l}\text { Amorphous } \mathrm{FePO}_{4} \\
\text { crystalline } \mathrm{FePO}_{4}\end{array}$ & $\mathrm{As}(\mathrm{III}) / \mathrm{As}(\mathrm{V})$ & $\begin{array}{l}21 / 10 \\
16 / 9\end{array}$ & $\begin{array}{l}\text { As (III) oxidized to } \mathrm{As}(\mathrm{V}) \text {, replacing phosphate group, producing } \\
\mathrm{Fe}_{3}\left(\mathrm{AsO}_{4}\right)_{2} \cdot 8 \mathrm{H}_{2} \mathrm{O} \text { and } \mathrm{FeAsO}_{4} \cdot 2 \mathrm{H}_{2} \mathrm{O} \text { precipitation }\end{array}$ & [91] \\
\hline $\mathrm{FePO}_{4}$ & $\operatorname{As}(\mathrm{V})$ & & Anion exchange & [92] \\
\hline $\mathrm{FePO}_{4}(\mathrm{SCS})$ & $\mathrm{Cr}(\mathrm{VI})$ & 21 & & [94] \\
\hline $\mathrm{FePO}_{4}(\mathrm{SS})$ & & 13.2 & & \\
\hline $\mathrm{FePO}_{4}(\mathrm{SM})$ & & 12.1 & & \\
\hline $\mathrm{FePO}_{4}$ & $\mathrm{Cr}(I I I)$ & 8.12 & Electrostatic interaction and coordination & [95] \\
\hline $\begin{array}{l}\mathrm{FePO}_{4} \\
\text { different sizes }\end{array}$ & $\mathrm{Cr}(I I I)$ & $\begin{array}{l}0.182 \pm \\
0.005^{c}\end{array}$ & & {$[27]$} \\
\hline $\mathrm{FePO}_{4}$ (microsheet) & $\mathrm{Cr}(\mathrm{III})$ & 14.17 & Consistent with 92 & [96] \\
\hline $\mathrm{FePO}_{4}$ (microsphere) & & 9.90 & & \\
\hline $\mathrm{FePO}_{4}$ (nanoparticle) & & 5.30 & & \\
\hline Vivianite $\mathrm{Fe}_{3}\left(\mathrm{PO}_{4}\right)_{2} \cdot\left(\mathrm{H}_{2} \mathrm{O}\right)_{8}$ & $\mathrm{Cr}(\mathrm{VI})$ & & Reduced to $\mathrm{Cr}$ (III) via adsorption and inner-sphere complexation & {$[97]$} \\
\hline $\mathrm{FePO}_{4}-\mathrm{MWNTs}$ & $\mathrm{Cd}(\mathrm{II})$ & 32.68 & & [98] \\
\hline $\mathrm{Fe}_{3} \mathrm{O}_{4} @ \mathrm{FePO}_{4}$ nanoparticles & $\mathrm{Cd}(\mathrm{II})$ & 13.51 & Electrostatic interaction, ion insertion and coordination & [99] \\
\hline pollen@FePO 4 & $\mathrm{Cd}(\mathrm{II})$ & 4.20 & Electrostatic and complexation & \\
\hline microspheres ${ }^{d}$ & $\mathrm{~Pb}(\mathrm{II})$ & 61.35 & Mainly complexation & \\
\hline \multirow[t]{2}{*}{$\mathrm{FePO}_{4} \cdot 2 \mathrm{H}_{2} \mathrm{O}$} & $\mathrm{Cd}(\mathrm{II})$ & 51.7 & Ion-exchange & {$[100]$} \\
\hline & $\mathrm{Pb}(\mathrm{II})$ & 151.2 & Chemical adsorption & {$[101]$} \\
\hline \multirow[t]{3}{*}{ Hybrid bio-nanocomposites } & As(III) & 162.00 & $\mathrm{Cd}(\mathrm{II}), \mathrm{Pb}(\mathrm{Il})$ : transformation of hydroxyl groups and precipitation & {$[102]$} \\
\hline & $\mathrm{Cd}(\mathrm{II})$ & 205.83 & with phosphate & \\
\hline & $\mathrm{Pb}(\mathrm{II})$ & 730.79 & & \\
\hline $\begin{array}{l}\text { Cellulose-stabilized } \\
\text { nanoparticles }\end{array}$ & $\begin{array}{l}\mathrm{Pb}(\mathrm{II}) \\
\mathrm{Cu}(\mathrm{II})\end{array}$ & & $\mathrm{Cu}(\mathrm{II})$ : formation of $\mathrm{Cu}_{3}\left(\mathrm{PO}_{4}\right)_{2}$ and $\mathrm{Cu}_{5}\left(\mathrm{PO}_{4}\right)_{3} \mathrm{OH}$ & $\begin{array}{l}{[103,} \\
104]\end{array}$ \\
\hline
\end{tabular}

Langmuir model, corresponding to an adsorption capacity of $61.88 \mathrm{mg} \mathrm{g}^{-1}$. The adsorbed DNA could be readily recovered by using a $0.04 \mathrm{~mol} \mathrm{~L}^{-1} \mathrm{BR}$ buffer at $\mathrm{pH} 10$. The nanocomposites were further used for the isolation of DNA from a series of real sample matrices.

\subsection{Radioactive element}

Iron phosphate has shown great value in the treatment of radioactive wastewater. The nano-size hierarchical $\mathrm{Fe}_{4}\left(\mathrm{P}_{2} \mathrm{O}_{7}\right)_{3}$ with high stability in solution, synthesized by using high temperature solid state reaction method, was applied to adsorb U(VI) ions from aqueous solutions [83]. The maximum sorption capacity of $\mathrm{Fe}_{4}\left(\mathrm{P}_{2} \mathrm{O}_{7}\right)_{3}$ towards $\mathrm{U}(\mathrm{VI})$ at $\mathrm{pH} 5.5$ was calculated to be $14 \mathrm{mg} \mathrm{g}^{-1}$. The sorption of $\mathrm{U}(\mathrm{VI})$ is mainly dominated by inner-sphere surface com- plexation, which was a spontaneous and endothermic process. The ultra-thin iron phosphate nanosheets with finecontrolled morphology were used as a new 2D material for uranium adsorption [41]. It shows an extreme-high U(VI) adsorption capacity of $704.23 \mathrm{mg} \mathrm{g}^{-1}$, about 27 times of conventional 3D material $\left(24.51 \mathrm{mg} \mathrm{g}^{-1}\right)$ and higher than most 2D absorbent materials. The sorption is spontaneous and endothermic, and can be conformed to single molecular layer adsorption. The possible adsorption mechanism can be described as a Monolayer Surface Complexation and Stacking mode. 


\subsection{Alkali metals, alkaline earth metals and some divalent metal cations}

Mustafa and Naeem et al. studied the adsorption performance of iron phosphate on alkali metals $\left(\mathrm{Li}^{+}, \mathrm{Na}^{+}, \mathrm{K}^{+}\right)$, alkaline earth metals $\left(\mathrm{Ca}^{2+}, \mathrm{Mg}^{2+}\right)$ and divalent metal cations $\left(\mathrm{Zn}^{2+}, \mathrm{Cu}^{2+}, \mathrm{Ni}^{2+}, \mathrm{Co}^{2+}\right)$ [84-88]. They consider that the adsorption mechanism is related to the ion exchange between protons on the surface of iron phosphate and metal cations in the solution.

Potentiometric titrations of iron(III) phosphate have shown an apparently weak monobasic acid behavior towards alkali, alkaline earth and divalent transition metal ions [85]. The selectivity sequence and dissociation of the exchanger was found to increase in the order $\mathrm{Cu}^{2+}>\mathrm{Zn}^{2+}$ $>\mathrm{Ni}^{2+}>\mathrm{Ca}^{2+}>\mathrm{K}^{+}$. The sorption process of iron(III) phosphate toward $\mathrm{Zn}^{2+}$ was found to be endothermic in nature and the dissociation process was also observed to be endothermic [86]. Naeem et al. [88] further studied adsorption of $\mathrm{Cu}^{2+}$ and $\mathrm{Co}^{2+}$ ions from the aqueous electrolyte solution onto the $\mathrm{FePO}_{4}$. The isosteric heat $(\Delta \mathrm{H})$ of metal ions sorption showed that the adsorption reaction is endothermic and the surface of $\mathrm{FePO}_{4}$ is energetically heterogeneous. The desorption mechanism might be cation exchange, between the metal ions released from metal loaded surface of $\mathrm{FePO}_{4}$ and $\mathrm{H}^{+}$adsorbed from the aqueous solution into the solid phase. The mechanism for adsorption and desorption of metal ions can be proposed according to the reactions 1 and 2, respectively.

$$
\begin{aligned}
& \mathrm{P}-\mathrm{OH}+\mathrm{M}^{+} \Leftrightarrow \mathrm{P}-\mathrm{OM}+\mathrm{H}^{+} \\
& \mathrm{P}-\mathrm{OM}+\mathrm{H}^{+} \Leftrightarrow \mathrm{P}-\mathrm{OH}+\mathrm{M}^{+}
\end{aligned}
$$

Where $\mathrm{P}$ stands for the solid surface and $\mathrm{M}^{+}$represents divalent metal ion in its hydrolyzed form $\left(\mathrm{MOH}^{+}\right)$.

\subsection{Heavy metals}

Yin et al. [31] studied the adsorption properties of amorphous iron(III) phosphate for heavy metal ions and found that its excellent absorption capacity for $\mathrm{Hg}$ (II) and $\mathrm{Ag}$ (I) could reach to $1.831 \mathrm{mmol} \mathrm{g}^{-1}$ and $1.354 \mathrm{mmol} \mathrm{g}^{-1}$, respectively, at $\mathrm{pH}=5.98$. The adsorption properties for $\mathrm{Hg}(\mathrm{II})$ were stronger than those for $\mathrm{Ag}(\mathrm{I})$.

Xia et al. [89] prepared a complex polymeric ferrum oxydatum phosphate and studied its flocculation in 2000. The results predict that it will be a flocculating agent with good stability. It can also be used to concentrate micro amounts of cadmium in water as a new inorganic co- precipitator [90]. Over 95\% of Cd was adsorbed. The determination of $\mathrm{Cd}$ in river water samples was achieved by using spectrophotometry.

Lenoble et al. [91] considered that both amorphous and crystalline iron(III) phosphate were efficient at arsenic removal. Results showed that the maximum adsorption capacities were higher towards As(III), i.e., $21 \mathrm{mg} \mathrm{g}^{-1}$ and 16 $\mathrm{mg} \mathrm{g}^{-1}$, and, the capacities to $\mathrm{As}(\mathrm{V})$ were $10 \mathrm{mg} \mathrm{g}^{-1}$ and $9 \mathrm{mg} \mathrm{g}^{-1}$, respectively. The mechanism might involve: As (III) is oxidized to $\mathrm{As}(\mathrm{V})$ by $\mathrm{Fe}$ (III), and then $\mathrm{As}(\mathrm{V})$ replaces the phosphate group in iron phosphate, resulting in the precipitation of $\mathrm{Fe}_{3}\left(\mathrm{AsO}_{4}\right)_{2} \cdot 8 \mathrm{H}_{2} \mathrm{O}$ and $\mathrm{FeAsO}_{4} \cdot 2 \mathrm{H}_{2} \mathrm{O}$. This sorbent could be a potential candidate for industrial waste treatment, although the high release of phosphate and iron will exclude its application in drinking water plants. Hamayun et al. [92] studied the equilibrium and kinetics of $\mathrm{H}_{2} \mathrm{AsO}_{4}^{-}$adsorption by $\mathrm{FePO}_{4}$. Adsorption of arsenic on $\mathrm{FePO}_{4}$ was favorable in lower $\mathrm{pH}$ range at higher temperature. Anion exchange process might be responsible for the uptake of $\mathrm{H}_{2} \mathrm{AsO}_{4}^{-}$onto $\mathrm{FePO}_{4}$. He et al. [93] discussed the effects of $\mathrm{pH}$, arsenic concentration, temperature and mixing speed on adsorption performances of iron phosphate for arsenic. The adsorption efficiency of arsenic adsorption reached $99.6 \%$ under the optimum conditions: initial arsenic concentration of $0.0001 \mathrm{~mol} \mathrm{~L}^{-1}$, $\mathrm{pH}$ of 7 , stirring speed of $600 \mathrm{r} \mathrm{min}^{-1}$, temperature of $80^{\circ} \mathrm{C}$, reaction time of $1 \mathrm{~h}$. It was considered meaningful to solve the arsenic pollution problem in drinking water or soil.

Baykan et al. [94] prepared iron orthophosphate by different methods. The equilibrium data for the adsorption of chromium on the prepared materials were analyzed in Langmuir and Freundlich isotherm models. The adsorption process could be described by pseudo-secondorder kinetic model. The maximum adsorption capacity of $\mathrm{Cr}(\mathrm{VI})$ on the iron orthophosphate synthesized by solution combustion (SCS), solid state (SSS), and solution method (SM) are 21, 13.2, and $12.1 \mathrm{mg} \mathrm{g}^{-1}$, respectively, at $100 \mathrm{ppm}$ chromium concentration with $1 \mathrm{~g} \mathrm{~L}^{-1}$ adsorbent dose for $2 \mathrm{~h}$. The solution combustion synthesized material is the most efficient adsorbent because of its high surface area. The research shows that iron orthophosphate is cheap and easy to operate for adsorption of $\mathrm{Cr}(\mathrm{VI})$ from wastewater.

The author has been studying the adsorption behavior and mechanism of iron phosphate for heavy metals in recent years. One of the studies showed that $\mathrm{Cr}$ (III) was adsorbed on the prepared iron phosphate with an ca. $62 / 1$ selectivity over $\mathrm{Cr}$ (VI) [95]. The adsorption of $\mathrm{Cr}$ (III) fits Langmuir model, corresponding to a maximum adsorption capacity of $8.12 \mathrm{mg} \mathrm{g}^{-1}$. The retained $\mathrm{Cr}(\mathrm{III})$ could be readily recovered and quantified with detection by electrothermal atomic absorption spectrometry (ETAAS), with an enrich- 
ment factor of 8.7 and a detection limit (LOD) of $0.02 \mu \mathrm{g} \mathrm{L}^{-1}$. Total chromium was determined after reduction of $\mathrm{Cr}(\mathrm{VI})$ to $\mathrm{Cr}(\mathrm{III})$. The content of $\mathrm{Cr}(\mathrm{VI})$ was achieved by difference. Thus, chromium speciation of different kinds of environmental samples was achieved. The adsorption mechanism was related to electrostatic and coordination. Zhang et al. [27] studied the adsorption of $\mathrm{Cr}(\mathrm{III})$ on $\mathrm{FePO}_{4}$ nanoparticles with different sizes. The adsorption of capacity was in proportion to the specific surface area. The same $\mathrm{Cr}$ (III) adsorption capacity was obtained as $0.182 \pm 0.005 \mathrm{mg} \mathrm{m}^{-2}$ when expressing the results as per $\mathrm{m}^{2}$ adsorbent. They further realized morphology control of iron phosphate from amorphous nanoparticle to monoclinic microsheet or microsphere simply by only changing the addition of $\mathrm{H}_{3} \mathrm{PO}_{4}$ in the reaction system [96]. The maximum adsorption capacities of $\mathrm{Cr}$ (III) for different morphologies of nanoparticle, microsheet, and microsphere are 5.30, 14.17, and 9.90 $\mathrm{mg} \mathrm{g}^{1}$, respectively. The result is not proportional to the surface area and pore volume. The adsorption behavior is consistent with the explanation of adsorption mechanism in literature [95]. Bae et al. [97] conducted experimental and theoretical studies to identify the molecularscale reaction mechanism for $\mathrm{Cr}(\mathrm{VI})$ removal by a ferrous phosphate mineral, vivianite, $\mathrm{Fe}_{3}\left(\mathrm{PO}_{4}\right)_{2} \cdot\left(\mathrm{H}_{2} \mathrm{O}\right)_{8} \cdot \mathrm{Cr}(\mathrm{VI})$ is readily reduced to $\mathrm{Cr}$ (III) by vivianite via adsorption and inner-sphere complexation, suggesting that in anoxic ironphosphate-enriched environments, vivianite may significantly influence the fate and transport of $\mathrm{Cr}(\mathrm{VI})$.

The author modified multi-walled carbon nanotubes with iron phosphate to obtain a composite material $\mathrm{FePO}_{4}$ MWNTs for the purpose of improving its selectivity and sorption capacity to cadmium [98]. The $\mathrm{FePO}_{4}$-MWNTs offer a much-improved sorption capacity of $32.68 \mathrm{mg} \mathrm{g}^{1}$ for cadmium over $6.72 \mathrm{mg} \mathrm{g}^{1}$ by bare carbon nanotubes after oxidation at $\mathrm{pH} 6$. The composites were packed into a mini-column for on-line selective preconcentration of cadmium with detection by ETAAS, with an enhancement factor of 31.2 and LOD of $1.3 \mathrm{ng} \mathrm{L}^{-1}$. In the author's another work [99], superparamagnetic $\mathrm{Fe}_{3} \mathrm{O}_{4} @ \mathrm{FePO}_{4}$ nanoparticles with core shell structure were prepared by coating iron phosphate on the surface of $\mathrm{Fe}_{3} \mathrm{O}_{4}$ nanoparticles by liquid phase deposition method. Its unique magnetic properties are favorable for rapid separation and preconcentration of trace cadmium from aqueous solutions. The adsorption of Cd(II) fits Langmuir model, deriving a maximum adsorption capacity of $13.51 \mathrm{mg} \mathrm{g}^{1}$. The retained Cd(II) could be readily recovered with detection by ETAAS, along with an enrichment factor of 10.3 and LOD of $0.021 \mu \mathrm{g} \mathrm{L}^{-1}$. In addition, the adsorption mechanism of $\mathrm{Cd}(\mathrm{II})$ onto the surface of $\mathrm{Fe}_{3} \mathrm{O}_{4} @ \mathrm{FePO}_{4}$ nanoparticles might involve electrostatic interaction, ion insertion and coordination. In the author's recent work not published, the maximum adsorption capacities of iron phosphate modified pollen microspheres (pollen@ $\mathrm{FePO}_{4}$ ) for $\mathrm{Cd}(\mathrm{II})$ and $\mathrm{Pb}(\mathrm{II})$ are 4.20 and $61.35 \mathrm{mg} \mathrm{g}^{1}$, respectively. The preliminary study showed that the adsorption mechanism of $\mathrm{Cd}(\mathrm{II})$ is related to electrostatic and complexation, and that for $\mathrm{Pb}$ (II) is mainly complexation.

Phosphated residue generated from iron and steel plants, mainly composed of $\mathrm{FePO}_{4} \cdot 2 \mathrm{H}_{2} \mathrm{O}$, can be directly reused for removing $\mathrm{Pb}^{2+}$ and $\mathrm{Cd}^{2+}$ from wastewater by adsorption $[100,101]$. The sorption behavior of $\mathrm{Cd}^{2+}$ and $\mathrm{Pb}^{2+}$ could be described better by pseudo-second order kinetic model and Langmuir isotherm model. The maximum adsorption capacities for $\mathrm{Cd}^{2+}$ and $\mathrm{Pb}^{2+}$ derived from Langmuir model were 51.7, $151.2 \mathrm{mg} \mathrm{g}^{-1}$, respectively. The possible adsorption mechanism of $\mathrm{Cd}^{2+}$ was mainly the ion-exchange between the metal cation $\mathrm{Cd}^{2+}$ and $\mathrm{Fe}$ of the phosphated residue. The mechanism of $\mathrm{Pb}^{2+}$ sorption might be chemical adsorption predominantly by dissolution of $\mathrm{FePO}_{4} \cdot 2 \mathrm{H}_{2} \mathrm{O}$ and formation of precipitation, i.e., $\mathrm{Pb}_{3}\left(\mathrm{PO}_{4}\right)_{2}$ and $\mathrm{Pb}_{5}\left(\mathrm{PO}_{4}\right)_{3} \mathrm{OH}$. Simultaneous adsorption of $\mathrm{As}(\mathrm{III}), \mathrm{Cd}(\mathrm{II})$ and $\mathrm{Pb}$ (II) by hybrid bio-nanocomposites of nano hydroxy ferric phosphate and hydroxy ferric sulfate particles coating on Aspergillus niger was studied [102]. The adsorption capacities for $\mathrm{As}(\mathrm{III}), \mathrm{Cd}(\mathrm{II})$, and $\mathrm{Pb}(\mathrm{II})$ were $162.00,205.83$ and $730.79 \mathrm{mg} \mathrm{g}^{-1}$, respectively. The adsorption of $\mathrm{Cd}(\mathrm{II})$ and $\mathrm{Pb}(\mathrm{ll})$ was associated with transformation of hydroxyl groups and precipitation with phosphate.

The sorption of heavy metals on iron phosphate materials also plays a role in the remediation of polluted soils. Liu et al. [103, 104] prepared and tested sodium carboxymethyl cellulose-stabilized iron phosphate nanoparticles for in-situ immobilization of heavy metals in soils. The particle size was $8.4 \pm 2.9 \mathrm{~nm}$. The nanoparticles can effectively reduce the leachability and bioaccessibility of $\mathrm{Pb}$ and $\mathrm{Cu}$ in three representative soils (calcareous, neutral, and acidic). The results showed that the leachability of $\mathrm{Pb}$ and $\mathrm{Cu}$ was reduced by $85-95 \%$ and $63-87 \%$, and the bioaccessibility was lowered by $31-47 \%$ and $54-69 \%$ after the soils were treated for 56 days. The formation of copper phosphate minerals through precipitation and adsorption was probably responsible for the decrease of $\mathrm{Cu}$ availability in soils [104]. Further tests revealed the formation of $\mathrm{Cu}_{3}\left(\mathrm{PO}_{4}\right)_{2}$ and $\mathrm{Cu}_{5}\left(\mathrm{PO}_{4}\right)_{3} \mathrm{OH}$ resulting in the decreased solubility of the $\mathrm{Cu}(\mathrm{II})$ in the acidic $\mathrm{pH}$ range. Yuan et al. [105] prepared a polymeric hydroxyl ferric phosphate (PHFP) from industrial byproducts for in-situ immobilization of $\mathrm{Cd}(\mathrm{II})$ and $\mathrm{Pb}(\mathrm{II})$ in soils. PHFP amendment can enhance the formation of stable $\mathrm{Cd}$ and $\mathrm{Pb}$ fractions and decrease $\mathrm{Cd}$ and $\mathrm{Pb}$ bioavailability. The removal rates of 
DTPA-extractable $\mathrm{Cd}$ and $\mathrm{Pb}$ in soils reached up to $33 \%$ and $45 \%$, and the water-soluble $\mathrm{Cd}$ and $\mathrm{Pb}$ decreased by $56 \%$ and 58\%, respectively, when PHFP was added in soils at $4 \%$ dosage. $\mathrm{Cd}$ and $\mathrm{Pb}$ release amount in PHFP amended soil declined by $53 \%$ and $52 \%$, respectively, as compared with non-treated soil. The result implied that PHFP had a potential application for the remediation of $\mathrm{Cd}$ - and $\mathrm{Pb}$ contaminated soils.

\section{Conclusion}

Iron phosphates synthesized by different methods might have various structures, morphologies and sizes. They are non-toxic and pollution-free with good biocompatibility. They have good performances in the fields of catalysis and battery electrode material rising in recent years, as well as in the traditional fields like agriculture and steel. Because of their unique structural characteristics, they also have important applications in adsorption, separation and concentration, and have broad application foreground.

As far as the application of iron phosphates in adsorption, separation and concentration is concerned, the current scope includes biomolecules, a radioactive element, alkali metals, alkaline earth metals and heavy metals. It is of great significance for the purification of wastewater and polluted soil, and the detection of specific ions, molecules and species in environmental and biological samples. In particular, iron phosphates have shown considerable adsorption properties for heavy metal pollutants, however, their comprehensive performance such as adsorption capacity, selectivity and separation efficiency needs to be improved, and the understanding of adsorption mechanisms is still not deep enough. Therefore, the next step is to study the interaction between different kinds of heavy metal ions and iron phosphate materials at the molecular/atomic level to reveal the microscopic adsorption mechanism. At the same time, it is necessary to systematically study the adsorption properties of iron phosphates on heavy metal ions in various environments, and select novel adsorption materials with fast speed, high selectivity and high adsorption capacity, so as to open up a new path toward effective control of heavy metal pollutants in the human living environment.

Acknowledgement: This work was supported by the National Natural Science Foundation of China (21407018, 41576111) and the Fundamental Research Funds for the Central Universities (3132015221).

\section{References}

[1] Aliouane, N., T. Badeche, Y. Gagou, E. Nigrelli, and P. SaintGregoire. Synthesis and phase transitions of iron phosphate. Ferroelectrics, Vol. 241, No. 1, 2000, pp. 255-262.

[2] Huang, C. Y., S. L.Wang, and K. H. Lii. Novel mixed-valence tetranuclear iron-oxygen clusters in the organically templated iron phosphate $\left[\mathrm{H}_{3} \mathrm{~N}\left(\mathrm{CH}_{2}\right)_{2} \mathrm{NH}_{3}\right]_{2} \mathrm{Fe}_{4} \mathrm{O}\left(\mathrm{PO}_{4}\right)_{4} \cdot \mathrm{H}_{2} \mathrm{O}$. Journal of Porous Materials, Vol. 5, No. 2, 1998, pp. 147-152.

[3] Riou-Cavellec, M., D. Riou, and G. Ferey. Magnetic iron phosphates with an open framework. Inorganica Chimica Acta, Vol. 291, No. 1-2, 1999, pp. 317-325.

[4] Cavellec, M., D. Riou, C. Ninclaus, J. M. Greneche, and G. Ferey. $\left[\mathrm{Fe}_{4}\left(\mathrm{PO}_{4}\right) 4 \mathrm{~F}_{2}\left(\mathrm{H}_{2} \mathrm{O}\right)_{3}\right] \cdot\left[\mathrm{C}_{6} \mathrm{H}_{14} \mathrm{~N}_{2}\right]$ or ULM-12, the first magnetic ferric phosphate with an open structure: Hydrothermal synthesis, structure, and magnetic propertie. Zeolites, Vol. 17, No. 3, 1996, pp. 250-260.

[5] Na, L. Y., Y. L. Liu, W. Q. Pang, and R. R. Xu. Solvothermal synthesis and characterization of a 3-D iron phosphate with exclusively four-coordinated iron. Wuji Huaxue Xuebao, Vol. 16, 2000, pp. 287-292.

[6] Guo, X. F., W. P. Ding, X. S. Wang, and Q. J. Yan. Synthesis of Novel Lamellar Iron Phosphate. Chemistry Letters, Vol. 12, No. 12, 2000, pp. 1368-1369.

[7] Guo, X. F., W. P. Ding, X. G. Wang, and Q. J. Yan. Synthesis of a novel mesoporous iron phosphate. Chemical Communications, Vol. 8, No. 8, 2001, pp. 709-710.

[8] Yu, D. H., C. Wu, Y. Kong, N. H. Xue, X. F. Guo, and W. P. Ding. Structural and Catalytic Investigation of Mesoporous Iron Phosphate. Journal of Physical Chemistry C, Vol. 111, No. 39, 2007, pp. 14394-14399.

[9] Santos-Pena, J., P. Soudan, C. Aren, G. Palomino, and S. Franger. Electrochemical properties of mesoporous iron phosphate in lithium batteries. Journal of Solid State Electrochemistry, Vol. 10, No. 1, 2006, pp. 1-9.

[10] Zhu, S. M., H. S. Zhou, M. Hibino, and I. Honma. Synthesis of Hexagonal Mesostructured $\mathrm{FePO}_{4}$ Using Cationic Surfactant as the Template. Chemistry Letters, Vol. 33, No. 6, 2004, pp. 774775.

[11] Bastakoti, B. P., Y. Q. Li, S. Guragain, M. Pramanik, S. M. Alshehri, T. Ahamad, et al. Synthesis of Mesoporous Transition-Metal Phosphates by Polymeric Micelle Assembly. Chemistry-a European Journal, Vol. 22, No. 22, 2016, pp. 7463-7467.

[12] Pramanik, M., M. Imura, J. J. Lin, J. Kim, J. H. Kim, and Y. Yamauchi. Shape-controlled synthesis of mesoporous iron phosphate materials with crystallized frameworks. Chemical Communications, Vol. 51, No. 72, 2015, pp. 13806-13809.

[13] Shi, Z. C., Y. X. Li, W. L. Ye, and Y. Yang. Mesoporous FePO[sub 4] with Enhanced Electrochemical Performance as Cathode Materials of Rechargeable Lithium Batteries. Electrochemical and Solid-State Letters, Vol. 8, No. 8, 2005, pp. A396-A399.

[14] El Haskouri, J., A. Moragues, A. Beltran, S. Murcia-Mascaros, F. Plazaola, E. Legarra, et al. Mesoporous iron phosphate/phosphonate hybrid materials. Microporous and Mesoporous Materials, Vol. 187, 2014, pp. 14-22.

[15] Zhang, H. J., K. X. Wang, and J. S. Chen. Synthesis and electrochemical performance of a new spherical $\mathrm{LiFePO}_{4}$. Chemical Journal of Chinese Universities-Chinese, Vol. 32, 2011, pp. 641643. 
[16] Yu, Y. D., Y. J. Zhu, and J. Wu. Glycerin-assisted solvothermal synthesis of $\mathrm{Fe}_{3}\left(\mathrm{PO}_{4}\right)_{2}(\mathrm{OH})_{2}$ microspheres. Materials Letters, Vol. 205, 2017, pp. 158-161.

[17] Song, H. J., Y. L. Sun, and X. H. Jia. Hydrothermal synthesis of iron phosphate microspheres constructed by mesoporous polyhedral nanocrystals. Materials Characterization, Vol. 107, 2015, pp.182188.

[18] Liu, Y., Z. L. Li, Y. H. You, X. G. Zheng, and J. Wen. Synthesis of different structured $\mathrm{FePO}_{4}$ for the enhanced conversion of methyl cellulose to 5-hydroxymethylfurfural. RSC Advances, Vol. 7, No. 81, 2017, pp. 51281-51289.

[19] Chen, C., W. Chen, J. Lu, D. R. Chu, Z. Y. Huo, Q. Peng, and Y. D. Li. Transition-Metal Phosphate Colloidal Spheres. Angewandte Chemie International Edition, Vol. 48, No. 26, 2009, pp. 48164819.

[20] Cao, F., and D. X. Li. Biotemplate synthesis of monodispersed iron phosphate hollow microspheres. Bioinspiration \& Biomimetics, Vol. 5, No. 1, 2010, id. 6.

[21] Cao, S. W., Y. J. Zhu, and J. B. Cui. Iron hydroxyl phosphate microspheres: Microwave-solvothermal ionic liquid synthesis, morphology control, and photoluminescent properties. Journal of Solid State Chemistry, Vol. 183, No. 7, 2010, pp. 1704-1709.

[22] Yin, Y. J., P. Wu, H. Zhang, and C. X. Cai. Enhanced cathode performances of amorphous FePO4 hollow nanospheres with tunable shell thickness in lithium ion batteries. Electrochemistry Communications, Vol. 18, 2012, pp. 1-3.

[23] Yin, Y. J., Y. J. Hu, P. Wu, H. Zhang, and C. X. Cai. A grapheneamorphous $\mathrm{FePO}_{4}$ hollow nanosphere hybrid as a cathode material for lithium ion batteries. Chemical Communications, Vol. 48, No. 15, 2012, pp. 2137-2139.

[24] Guo, X. F., W. P. Ding, and Q. J. Yan. A new method of preparing nanoparticle - Quick homogeneous precipitation. Wuji Huaxue Xuebao, Vol. 16, 2000, pp. 527-530.

[25] Wang, X., X. H. Yang, H. G. Zheng, H. Y. Jin, and Z. Zhang. Synthesis and electrochemical performance of amorphous hydrated iron phosphate nanoparticles. Journal of Crystal Growth, Vol. 274, No. 1-2, 2005, pp. 214-217.

[26] Lu, Y. C., T. B. Zhang, Y. Liu, and G. S. Luo. Preparation of FePO4 nano-particles by coupling fast precipitation in membrane dispersion microcontactor and hydrothermal treatment. Chemical Engineering Journal, Vol. 210, 2012, pp. 18-25.

[27] Zhang, T. B., Y. C. Lu, and G. S. Luo. Size Adjustment of Iron Phosphate Nanoparticles by Using Mixed Acids. Industrial \& Engineering Chemistry Research, Vol. 52, No. 21, 2013, pp. 69626968.

[28] Fang, Y., L. Xiao, J. Qian, X. Ai, H. Yang, and Y. Cao. Mesoporous amorphous $\mathrm{FePO}_{4}$ nanospheres as high-performance cathode material for sodium-ion batteries. Nano Letters, Vol. 14, No. 6, Jun. 11, 2014, pp. 3539-3543.

[29] Hu, G. R., X. M. Xie, Z. D. Peng, K. Du, Z. G. Gan, L. Xu, et al. Novel synthesis of $\mathrm{FePO}_{4} \cdot 2 \mathrm{H}_{2} \mathrm{O}$ nanoparticles as a precursor of $\mathrm{LiFePO}_{4} / \mathrm{C}$ cathode material for lithium ion batteries by $\mathrm{mi}$ croreaction technology. Solid State lonics, Vol. 340, 2019, UNSP 115014.

[30] Yang, H. J., H. J. Song, H. J. Shin, and H. C. Choi. A rapid synthesis of iron phosphate nanoparticles via surface-mediated spontaneous reaction for the growth of high-yield, single-walled carbon nanotubes. Langmuir, Vol. 21, No. 20, Sep. 27, 2005, pp. 9098-9102.
[31] Yin, P., Y. C. Hu, Y. H. Sun, Y. X. Yang, C. N. Ji, Q. Xu, X. H. Xu, and W. J. Zhang. Solid-state synthesis of amorphous iron(III) phosphate at room temperature and its absorption properties for $\mathrm{Hg}(\mathrm{II})$ and $\mathrm{Ag}(\mathrm{I})$ ions. Materials Letters, Vol. 61, No. 17, 2007, pp. 3755-3757.

[32] Yin, Y. J., H. Zhang, P.Wu, B. Zhou, and C. X. Cai. Iron phosphate nanostructures synthesized by microwave method and their applications in biosensing. Nanotechnology, Vol. 21, 2010, id. 425504.

[33] Qian, L. C., Y. Xia, W. K. Zhang, H. Huang, Y. P. Gan, H. J. Zeng, et al. Electrochemical synthesis of mesoporous FePO4 nanoparticles for fabricating high performance $\mathrm{LiFePO}_{4} / \mathrm{C}$ cathode materials. Microporous and Mesoporous Materials, Vol. 152, 2012, pp. 128133.

[34] Liu, X. M., P. Yan, Y. Y. Xie, H. Yang, X. D. Shen, and Z. F. Ma. Synthesis of superior fast charging-discharging nano-LiFePO ${ }_{4} / \mathrm{C}$ from nano- $\mathrm{FePO}_{4}$ generated using a confined area impinging jet reactor approach. Chemical Communications, Vol. 49, No. 47, 2013, pp. 5396-5398.

[35] Yang, F., H. Zhang, Y. J. Shao, H. Y. Song, S. J. Liao, and J. W. Ren. Formic acid as additive for the preparation of high-performance FePO4 materials by spray drying method. Ceramics International, Vol. 43, No. 18, 2017, pp. 16652-16658.

[36] Yu, D., J. Qian, N. Xue, D. Zhang, C. Wang, X. Guo, et al. Mesoporous nanotubes of iron phosphate: Synthesis, characterization, and catalytic property. Langmuir, Vol. 23, No. 2, 2007, pp. 382-386.

[37] Cai, R., H. Liu, W. Zhang, H. Tan, D. Yang, Y. Huang, et al. Controlled synthesis of double-wall a-FePO 4 nanotubes and their LIB cathode properties. Small, Vol. 9, No. 7, 2013, pp. 1036-1041.

[38] Liu, H. W. Synthesis of nanorods $\mathrm{FePO}_{4}$ via a facile route. Journal of Nanoparticle Research, Vol. 12, No. 6, 2010, pp. 2003-2006.

[39] Liu, H. W., H. M. Yang, and J. L. Li. A novel method for preparing LiFePO4 nanorods as a cathode material for lithium-ion power batteries. Electrochimica Acta, Vol. 55, No. 5, 2010, pp. 16261629.

[40] Lee, Y. J., and A. M. Belcher. Nanostructure design of amorphous $\mathrm{FePO}_{4}$ facilitated by a virus for $3 \mathrm{~V}$ lithium ion battery cathodes. Journal of Materials Chemistry, Vol. 21, No. 4, 2011, pp. 10331039.

[41] Wang, D., Y. Xu, D. Xiao, Q. Qiao, P. Yin, Z. Yang, et al. Ultra-thin iron phosphate nanosheets for high efficient $\mathrm{U}(\mathrm{VI})$ adsorption. Journal of Hazardous Materials, Vol. 371, 2019, pp. 83-93.

[42] Zhang, Y., Z. F. Yi, J. S. Wang, L. M. Wei, L. X. Kong, and L. J. Wang. Sub-50 $\mathrm{nm}$ amorphous iron phosphate dihydrate nanoplates fabricated via liquid exfoliation from recycled steelmaking phosphate slag. Materials Letters, Vol. 233, 2018, pp. 290-293.

[43] Zhou, W. J., W. He, X. D. Zhang, S. P. Yan, X. A. Sun, X. Y. Tian, et al. Biosynthesis of iron phosphate nanopowders. Powder Technology, Vol. 194, No. 1-2, 2009, pp. 106-108.

[44] Yang, D., Z. Y. Lu, X. H. Rui, X. Huang, H. Li, J. X. Zhu, et al. Synthesis of Two-Dimensional Transition-Metal Phosphates with Highly Ordered Mesoporous Structures for Lithium-Ion Battery Applications. Angewandte Chemie International Edition, Vol. 53, No. 35, 2014, pp. 9352-9355.

[45] Zhao, P. Z., H. B. Liu, H. H. Zheng, Q. H. Tang, and Y. M. Guo. Facile synthesis of $\mathrm{FePO}_{4} \cdot 2 \mathrm{H}_{2} \mathrm{O}$ submicrometer-discs. Materials Letters, Vol. 123, 2014, pp. 128-130.

[46] Su, Y. J., Y. Zhang, Z. Chen, J. Z. Hai, X. B. Yang, and H. P. Liu. Preparation and characterization of ultrafine disc shaped ferric phosphate dihydrate. Journal of Wuhan Institute of Technology, 
Vol. 40, 2018, pp. 66-70.

[47] Song, Y., P. Y. Zavalij, M. Suzuki, and M. S. Whittingham. New iron(III) phosphate phases: Crystal structure and electrochemical and magnetic properties. Inorganic Chemistry, Vol. 41, No. 22, Nov. 4, 2002, pp. 5778-5786.

[48] Lin, R. H., A. P. Amrute, F. Krumeich, K. Lazar, R. Hauert, M. Yulikov, et al. Phase-controlled synthesis of iron phosphates via phosphation of $\beta$-FeOOH nanorods. CrystEngComm, Vol. 18, No. 18, 2016, pp. 3174-3185.

[49] Mogus-Milankovic, A., M. Rajic, A. Drasner, R. Trojko, and D. E. Day. Crystallisation of iron phosphate glasses. Physics and Chemistry of Glasses, Vol. 39, 1998, pp. 70-75.

[50] Bingham, P. A., R. J. Hand, and S. D. Forder. Doping of iron phosphate glasses with $\mathrm{Al}_{2} \mathrm{O}_{3}, \mathrm{SiO}_{2}$ or $\mathrm{B}_{2} \mathrm{O}_{3}$ for improved thermal stability. Materials Research Bulletin, Vol. 41, No. 9, 2006, pp. 1622-1630.

[51] Donald, I. W., B. L. Metcalfe, and R. N. J. Taylor. The immobilization of high level radioactive wastes using ceramics and glasses. Journal of Materials Science, Vol. 32, No. 22, 1997, pp. 58515887.

[52] Bingham, P. A., R. J. Hand, O. M. Hannant, S. D. Forder, and S. H. Kilcoyne. Effects of modifier additions on the thermal properties, chemical durability, oxidation state and structure of iron phosphate glasses. Journal of Non-Crystalline Solids, Vol. 355 No. 28-30, 2009, pp. 1526-1538.

[53] Mesko, M. G., D. E. Day, and B. C. Bunker. Immobilization of CsCl and SrF2 in iron phosphate glass. Waste Management (New York, N.Y.), Vol. 20, No. 4, 2000, pp. 271-278.

[54] Stoch, P., W. Szczerba, W. Bodnar, M. Ciecinska, A. Stoch, and E. Burkel. Structural properties of iron-phosphate glasses: Spectroscopic studies and ab initio simulations. Physical Chemistry Chemical Physics, Vol. 16, No. 37, 2014, pp. 19917-19927.

[55] Jolley, K., and R. Smith. Radiation tolerance of iron phosphate: A study of amorphous and crystalline structures. Journal of Nuclear Materials, Vol. 479, 2016, pp. 347-356.

[56] Choi, J., W. Um, and S. Choung. Development of iron phosphate ceramic waste form to immobilize radioactive waste solution. Journal of Nuclear Materials, Vol. 452, No. 1-3, 2014, pp. 16-23.

[57] Boras, C. A., R. Romagnoli, and R. O. Lezna. In-situ spectroelectrochemistry (UV-visible and infrared) of anodic films on iron in neutral phosphate solutions. Electrochimica Acta, Vol. 45, 2000, pp. 1717-1725.

[58] Ma, G. C., S.W. Ding, Q. Li, and J. P. Zhu. Studies on synthesis and properties of iron (III) phosphate. [Natural Science Edition]. Journal of Hebei University, Vol. 13, 1993, pp. 54-57.

[59] Palomar-Pardave, M., M. T. Ramirez-Silva, G. A. Vazquez-Coutino, M. Romero-Romo, H. Herrera-Hernandez, and M. G. M. de OcaYemha. Electrocrystallization mechanism of iron phosphate coatings onto mild steel electrode surfaces. Journal of Solid State Electrochemistry, Vol. 17, No. 2, 2013, pp. 459-466.

[60] Dudrova, E., M. Kabatova, R. Orinakova, and P. Hvizdos. Electrochemical corrosion of sintered composites on the basis of $\mathrm{Fe} / \mathrm{FePO}_{4}$ coated powders. International Journal of Electrochemical Science, Vol. 11, 2016, pp. 1751-1764.

[61] Sega, D., G. Ciuffreda, G. Mariotto, B. Baldan, A. Zamboni, and Z. Varanini. $\mathrm{FePO}_{4}$ nanoparticles produced by an industrially scalable continuous-flow method are an available form of $P$ and Fe for cucumber and maize plants. Scientific Reports, Vol. 9, No. 1, 2019, p. 11252.
[62] Zhang, Y., Z. F. Yi, L. M. Wei, L. X. Kong, and L. J. Wang. Modified iron phosphate/polyvinyl alcohol composite film for controlledrelease fertilisers. RSCAdvances, Vol. 8, No. 32, 2018, pp. 1814618152.

[63] Rohner, F., F. O. Ernst, M. Arnold, M. Hilbe, R. Biebinger, F. Ehrensperger, et al. Synthesis, characterization, and bioavailability in rats of ferric phosphate nanoparticles. Journal of Nutrition, Vol. 137, No. 3, 2007, pp. 614-619.

[64] von Moos, L. M., M. Schneider, F. M. Hilty, M. Hilbe, M. Arnold, N. Ziegler, et al. Iron phosphate nanoparticles for food fortification: Biological effects in rats and human cell lines. Nanotoxicology, Vol. 11, No. 4, 2017, pp. 496-506.

[65] Dilbar, A., T. Erkin, A. Xawkat, and Y. Abliz. Fabrication of composite optical waveguides based on thin films consisted of iron phosphate nanoparticles and their applications as ammonia gas sensor. Chinese Journal of Applied Chemistry, Vol. 27, 2010, pp. 965-969.

[66] Otsuka, K., and Y. Wang. Direct conversion of methane into oxygenates. Applied Catalysis a-General, Vol. 222, 2001, pp. 145161.

[67] Ren, T., L. Yan, H. P. Zhang, and J. S. Suo. Study on Fe-P-O based catalysts in the gas-phase direct oxidation of benzene to phenol with $\mathrm{N}_{2} \mathrm{O}$ as an oxidant. Journal of Molecular Catalysis (China), Vol. 17, 2003, pp. 342-346.

[68] Lopez-Pedrajas, S., R. Estevez, R. Navarro, D. Luna, F. M. Bautista. Catalytic behaviour of mesoporous metal phosphates in the gasphase glycerol transformation. Journal of Molecular Catalysis a-Chemical, Vol. 421, 2016, pp. 92-101.

[69] Behbahani, F. K., and B. Yazdanparast. Iron(III) phosphate catalyzed synthesis of 1,4-dihydropyridines. Arabian Journal of Chemistry, Vol. 12, No. 7, 2019, pp. 1353-1357.

[70] Babar, P. T., A. C. Lokhande, H. J. Shim, M. G. Gang, B. S. Pawar, S. M. Pawar, et al. SILAR deposited iron phosphate as a bifunctional electrocatalyst for efficient water splitting. Journal of Colloid and Interface Science, Vol. 534, 2019, pp. 350-356.

[71] Guo, S., G. Zhang, and J. C. Yu. Enhanced photo-Fenton degradation of rhodamine $\mathrm{B}$ using graphene oxide-amorphous $\mathrm{FePO}_{4}$ as effective and stable heterogeneous catalyst. Journal of Colloid and Interface Science, Vol. 448, 2015, pp. 460-466.

[72] Zhou, H., X. Y. Yue, H. W. Lv, L. R. Kong, Z. Y. Ji, and X. P. Shen. Graphene oxide- $\mathrm{FePO}_{4}$ nanocomposite: Synthesis, characterization and photocatalytic properties as a Fenton-like catalyst. Ceramics International, Vol. 44, No. 6, 2018, pp. 7240-7244.

[73] Zhu, Y. M., Z. W. Ruan, S. Z. Tang, and V. Thangadurai. Research status in preparation of $\mathrm{FePO}_{4}$ : A review. lonics, Vol. 20, No. 11, 2014, pp. 1501-1510.

[74] Padhi, A. K., K. S. Nanjundaswamy, and J. B. Goodenough. Phospho-olivines as Positive-Electrode Materials for Rechargeable Lithium Batteries. Journal of the Electrochemical Society, Vol. 144, No. 4, 1997, pp. 1188-1194.

[75] Prosini, P. P., D. Zane, and M. Pasquali. Improved electrochemical performance of a LiFePO4-based composite cathode. Electrochimica Acta, Vol. 46, No. 23, 2001, pp. 3517-3523.

[76] Wang, Z., and Y. Lu. Facile Construction of High-Performance Amorphous $\mathrm{FePO}_{4} /$ Carbon Nanomaterials as Cathodes of Lithium-Ion Batteries. ACS Applied Materials \& Interfaces, Vol. 11, No. 14, 2019, pp. 13225-13233.

[77] Liu, Y., Y. R. Zhou, J. X. Zhang, S. M. Zhang, and P. Ren. The relation between the structure and electrochemical performance of sodiated iron phosphate in sodium-ion batteries. Journal of 
Power Sources, Vol. 314, 2016, pp. 1-9.

[78] Shan, P., Y. Gu, L. Yang, T. Liu, J. Zheng, and F. Pan. Olivine $\mathrm{FePO}_{4}$ Cathode Material for Rechargeable Mg-Ion Batteries. Inorganic Chemistry, Vol. 56, No. 21, 2017, pp. 13411-13416.

[79] Huang, C. Y., Y. Zhou, H. B. Shu, M. F. Chen, Q. Q. Liang, S. X. jiang, et al. Synergetic restriction to polysulfides by hollow $\mathrm{FePO}_{4}$ nanospheres wrapped by reduced graphene oxide for lithiumsulfur battery. Electrochimica Acta, Vol. 329, 2020, UNSP 135135.

[80] Kandori, K., T. Kuwae, and T. Ishikawa. Control on size and adsorptive properties of spherical ferric phosphate particles. Journal of Colloid and Interface Science, Vol. 300, No. 1, 2006, pp. 225-231.

[81] Tang, S., W. Wang, X. Chen, and J. Wang. Fluoridized iron phosphate as a novel adsorbent for selective separation/isolation of cytochrome c. Analytical and Bioanalytical Chemistry, Vol. 401, No. 10, 2011, pp. 3283-3292.

[82] Hu, L. L., B. Hu, L. M. Shen, D. D. Zhang, X. W. Chen, and J. H. Wang. Polyethyleneimine-iron phosphate nanocomposite as a promising adsorbent for the isolation of DNA. Talanta, Vol. 132, 2015, pp. 857-863.

[83] Liu, X., Y. B. Xu, R. C. Jin, P. Yin, L. X. Sun, T. Liang, et al. Facile synthesis of hierarchical $\mathrm{Fe}_{4}\left(\mathrm{P}_{2} \mathrm{O}_{7}\right)_{3}$ for removal of $\mathrm{U}(\mathrm{VI})$. Journal of Molecular Liquids, Vol. 200, 2014, pp. 311-318.

[84] Mustafa, S., A. Naeem, S. U. Nisa, S. Murtaza, and M. Khalid. The Mechanism of Alkali Metal Ion Sorption by Iron(III) Phosphate. Adsorption Science and Technology, Vol. 17, No. 9, 1999, pp. 715727.

[85] Mustafa, S., A. Naeem, N. Rehana, and T. Hussain. Exchange of Some Divalent Metal Cations and Their Effect on the Dissociation of Iron(III) Phosphate. Adsorption Science and Technology, Vol. 13, No. 4, 1996, pp. 241-260.

[86] Mustafa, S., A. Naeem, S. Murtaza, N. Rehana, and H. Y. Samad. Comparative Sorption Properties of Metal(III) Phosphates. Journal of Colloid and Interface Science, Vol. 220, No. 1, 1999, pp. 63-74.

[87] Naeem, A., S. Mustafa, B. Dilara, A. Hamid, and S. Murtaza. Precipitation effect on $\mathrm{Mg}^{2+}$ ions sorption by $\mathrm{FePO}_{4}$. Journal of the Chemical Society of Pakistan, Vol. 26, 2004, pp. 360-362.

[88] Naeem, A., S. Mustafa, B. Dilara, M. Ilyas, H. Y. Samad, and M. Safdar. Sorption of isosteric heat of metal ions by $\mathrm{FePO}_{4}$. Journal of the Chemical Society of Pakistan, Vol. 29, 2007, pp. 1-4.

[89] Xia, Y. L., W. Jiao, Z. J. Wang, and Q. Yang. Synthesis of complex polymeric ferrum oxydatum phosphate and study on it's flocculation. [Natural Sciences Edition]. Journal of Heilongjiang Institute of Commerce, Vol. 16, 2000, pp. 90-93.

[90] Xia, Y. L., X. Lin, and W. Jiao. Concentration and determination of micro amounts of cadmium in water with complex polymeric ferrum oxydatum phosphate. [Natural Sciences Edition]. Journal of Heilongjiang Institute of Commerce, Vol. 16, 2000, pp. 73-76.

[91] Lenoble, V., C. Laclautre, V. Deluchat, B. Serpaud, and J. C. Bollinger. Arsenic removal by adsorption on iron(III) phosphate. Journal of Hazardous Materials, Vol. 123, No. 1-3, 2005, pp. 262268.

[92] Hamayun, M., T. Mahmood, A. Naeem, M. Muska, S. U. Din, and M. Waseem. Equilibrium and kinetics studies of arsenate adsorption by FePO(4). Chemosphere, Vol. 99, Mar. 2014, pp. 207-215.
[93] He, Q., and Q. Li, Study on adsorption properties of iron phosphate for arsenic. Guangzhou Chemical Industry, Vol. 42, 2014, pp. 65-67, 118 .

[94] Baykan, D., B. Aytekin, and N. A. Oztas. Removal of chromium(VI) from aqueous solution using iron orthophosphate that is synthesized by different methods. Desalination and Water Treatment, Vol. 56, No. 7, 2015, pp. 1855-1862.

[95] Zhang, X. X., S. S. Tang, M. L. Chen, and J. H. Wang. Iron phosphate as a novel sorbent for selective adsorption of chromium(iii) and chromium speciation with detection by ETAAS. Journal of Analytical Atomic Spectrometry, Vol. 27, No. 3, 2012, pp. 466-472.

[96] Zhang, T. B., Y. C. Lu, and G. S. Luo. Iron Phosphate Prepared by Coupling Precipitation and Aging: Morphology, Crystal Structure, and Cr(III) Adsorption. Crystal Growth \& Design, Vol. 13, No. 3, 2013, pp. 1099-1109.

[97] Bae, S., Y. Sihn, D. Kyung, S. Yoon, T. Eom, U. Kaplan, et al. Molecular Identification of $\mathrm{Cr}(\mathrm{VI})$ Removal Mechanism on Vivianite Surface. Environmental Science \& Technology, Vol. 52, No. 18, 2018, pp. 10647-10656.

[98] Zhang, X. X., L. P. Zhang, T. Yang, L. M. Shen, M. L. Chen, and J. $H$. Wang. Improvement on the selectivity and sorption capacity of cadmium by iron loaded carbon nanotubes with detection by electrothermal atomic absorption spectrometry. Journal of Analytical Atomic Spectrometry, Vol. 27, No. 10, 2012, pp. 16801687.

[99] Zhang, X., C. Sun, L. Zhang, H. Liu, B. Cao, L. Liu, et al. Adsorption studies of cadmium onto magnetic $\mathrm{Fe}_{3} \mathrm{O}_{4} @ \mathrm{FePO}_{4}$ and its preconcentration with detection by electrothermal atomic absorption spectrometry. Talanta, Vol. 181, 2018, pp. 352-358.

[100] Dong, X. L., Y. B. Yan, Y. Huang, F. L. Zheng, X. Y. Sun, and L. J. Wang, Recycling phosphated residue for adsorption of $\mathrm{Cd}^{2+}$ : adsorption performance and mechanism. Technology of Water Treatment, Vol. 42, 2016, pp. 22-26, 32.

[101] Dong, X. L., Y. B. Yan, X. Y. Sun, J. S. Li, W. Q. Han, J. Y. Shen, et al. Recycling Phosphated Residue for $\mathrm{Pb}^{2+}$ Removal from Wastewater. Environmental Engineering Science, Vol. 33, No. 3, 2016, pp. 207-214.

[102] Liao, Q., G. Tu, Z. Yang, H. Wang, L. He, J. Tang, et al. Simultaneous adsorption of $\mathrm{As}(\mathrm{III}), \mathrm{Cd}(\mathrm{II})$ and $\mathrm{Pb}$ (II) by hybrid bionanocomposites of nano hydroxy ferric phosphate and hydroxy ferric sulfate particles coating on Aspergillus niger. Chemosphere, Vol. 223, 2019, pp. 551-559.

[103] Liu, R., and D. Zhao. Reducing leachability and bioaccessibility of lead in soils using a new class of stabilized iron phosphate nanoparticles. Water Research, Vol. 41, No. 12, 2007, pp. 24912502.

[104] Liu, R., and D. Zhao. In situ immobilization of Cu(II) in soils using a new class of iron phosphate nanoparticles. Chemosphere, Vol. 68, No. 10, 2007, pp. 1867-1876.

[105] Yuan, Y. N., L. Y. Chai, Z. H. Yang, R. P. Wu, H. Liu, L. F. Liang, et al. Immobilization of $\mathrm{Cd}$ and $\mathrm{Pb}$ in soils by polymeric hydroxyl ferric phosphate. Transactions of Nonferrous Metals Society of China, Vol. 27, No. 5, 2017, pp. 1165-1171. 